\title{
Real-time RT-PCR for detection, identification and absolute quantification of viral haemorrhagic septicaemia virus using different types of standards
}

\author{
C. Lopez-Vazquez, I. Bandín, C. P. Dopazo* \\ Unidad de Ictiopatología, Departamento de Microbiología, Instituto de Acuicultura, Universidad de Santiago de Compostela, \\ 15782 Santiago de Compostela, Spain
}

\begin{abstract}
In the present study, 2 systems of real-time RT-PCR - one based on SYBR Green and the other on TaqMan - were designed to detect strains from any genotype of viral haemorrhagic septicaemia virus (VHSV), with high sensitivity and repeatability/reproducibility. In addition, the method was optimized for quantitative purposes (qRT-PCR), and standard curves with different types of reference templates were constructed and compared. Specificity was tested against 26 isolates from 4 genotypes. The sensitivity of the procedures was first tested against cell culture isolation, obtaining a limit of detection (LD) of $10^{0} \mathrm{TCID}_{50} \mathrm{ml}^{-1}$ (100-fold below the LD using cell culture), at a threshold cycle value (Ct) of 36. Sensitivity was also evaluated using RNA from crude (LD = 1 fg; 160 genome copies) and purified virus (100 ag; 16 copies), plasmid DNA ( 2 copies) and RNA transcript (15 copies). No differences between both chemistries were observed in sensitivity and dynamic range. To evaluate repeatability and reproducibility, all experiments were performed in triplicate and on 3 different days, by workers with different levels of experience, obtaining $\mathrm{Ct}$ values with coefficients of variation always $<5$. This fact, together with the high efficiency and $\mathrm{R}^{2}$ values of the standard curves, encouraged us to analyse the reliability of the method for viral quantification. The results not only demonstrated that the procedure can be used for detection, identification and quantification of this virus, but also demonstrated a clear correlation between the regression lines obtained with different standards, which will help scientists to compare sensitivity results between different studies.
\end{abstract}

KEY WORDS: qPCR · Viral haemorrhagic septicaemia virus $\cdot$ Quantification

- Resale or republication not permitted without written consent of the publisher

\section{INTRODUCTION}

Viral haemorrhagic septicaemia virus (VHSV) belongs to the family Rhabdoviridae, genus Novirhabdovirus, and has been associated with significant losses of wild and cultured freshwater and marine fish species. Since the first isolation of VHSV in Denmark (Jensen 1965), the virus has been detected in many countries worldwide, and has been isolated from over 70 fish species (OIE 2012).
The genome is composed of a single-stranded, non-segmented negative sense RNA genome of 11 to $12 \mathrm{~kb}$ (Schütze et al. 1999). It contains 6 open reading frames (3'-N-P-M-G-NV-L-5'), corresponding to the nucleocapsid- $(\mathrm{N})$, phospho- $(\mathrm{P})$, matrix- $(\mathrm{M})$, glyco$(\mathrm{G})$, non-virion (NV) and polymerase (L) proteins. Upon infection of the host, the 6 genes are transcribed progressively from the $3^{\prime}$ to $5^{\prime}$ end of the template viral RNA, and in decreasing molar frequencies (Kurath \& Leong 1985). Therefore, due to the initial 
position of the N-gene in the VHSV genome, $\mathrm{N}$ transcripts are the most abundant during viral infection and therefore have been the target of several molecular assays used to detect VHSV (López-Vázquez et al. 2006, Matejusova et al. 2008, Cutrín et al. 2009, Hope et al. 2010).

Due to the high mortalities and significant losses that VHSV causes in aquaculture facilities, rapid and reliable methods for VHSV detection are needed to prevent the spread of the disease. The currently used and accepted international standards for detection of VHSV (OIE 2012), including an initial procedure of viral isolation in cell culture, followed by reverse transcriptase polymerase chain reaction (RT-PCR), and nucleotide sequencing to confirm the presence of VHSV as the infectious agent. In recent years, real-time quantitative PCR (qPCR) has emerged as a powerful technique for the diagnosis of viral diseases, providing a tool to detect and quantify virus. In addition, qPCR is a reproducible and highly specific assay for the detection and quantification of the virus and it is also less time-consuming than any other method (Dopazo \& Bandín 2011). In this regard, qRT-PCR is a commonly used method for the detection of many RNA fish viruses, including VHSV and other fish rhabdoviruses, such as spring viraemia of carp virus (SVCV) and infectious haematopoietic necrosis virus (IHNV) (Purcell et al. 2006, Yue et al. 2008).

For the detection of PCR products during qRT-PCR, 2 chemistries are most commonly used: the DNA binding fluorophore SYBR Green I (Workenhe et al. 2008, Cutrín et al. 2009, Jiang et al. 2014) and the sequence-specific fluorescently labelled TaqMan probes (Chico et al. 2006, Matejusova et al. 2008, Garver et al. 2011).

Due to the limitations of previously published methods in terms of their specificity, sensitivity or applicability to the detection of all known genotypes of VHSV, we aimed to develop a universal assay for detection, identification and quantification of this virus in cell cultures. The procedure was designed for both systems, based on amplification of a $163 \mathrm{bp}$ fragment of the nucleoprotein (N) gene, to detect any genotype of VHSV and to improve the reliability of the diagnosis. The methods were evaluated in terms of sensitivity, specificity and repeatability and reproducibility. In addition, this report describes the comparison of plasmid DNA, in vitro transcribed RNA, purified virus and crude virus as standards for absolute viral quantification.

\section{MATERIALS AND METHODS}

\author{
Virus and cells
}

A total of 35 VHSV strains from genotypes I (including sublineages Ia, Ib, Id and Ie), II, III and IV (including sublineages IVa, IVb and IVc), including reference strains and local isolates, were assayed in silico and/or ex vivo (Table 1). In addition, 2 strains of IHNV type 1 (River Butte 91 and Applegate River 93) kindly provided by Dr. J. A. Leong (Hawaii Institute of Marine Biology, Kaneohe, Hawaii, USA) were included as negative controls. For viral propagation, epithelioma papulosum cyprini (EPC) cells, purchased from the European Collection of Cell Cultures (ECACC 93120820, Salisbury, UK), were employed. The cells were cultured at $25^{\circ} \mathrm{C}$ in minimum essential medium (EMEM) supplemented with $10 \%$ foetal bovine serum (FBS), penicillin and streptomycin (100 IU ml ${ }^{-1}$ and $100 \mu \mathrm{g} \mathrm{ml}^{-1}$, respectively). When the monolayers showed around $90 \%$ confluence, the medium was substituted by EMEM without FBS, and the virus was inoculated at a multiplicity of infection (MOI) of 0.1 to 1 ; infected monolayers were incubated at $15^{\circ} \mathrm{C}$ until the development of cytopathic effect. Viral titration was performed as described previously (Dopazo et al. 2002).

\section{RNA extraction}

The extraction of RNA was performed using Trizol ${ }^{\circledR}$ LS reagent (Gibco, BRL) as described by the manufacturer. The extracted RNA was finally resuspended in $50 \mu \mathrm{l}$ of diethyl pyrocarbonate (DEPC)-treated water, and quantified by absorbance measurement at $260 \mathrm{~nm}$ $\left(\mathrm{A}_{260}\right)$ in a Nanodrop ND-100 spectrophotometer (Nanodrop Technologies). The quality of the extracted RNA was evaluated from the absorbance ratio $A_{260}$ : $A_{280}$ (Sambrook \& Russell 2001). The concentration of

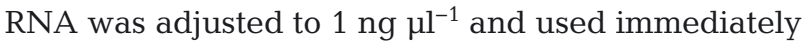
or stored at $-20^{\circ} \mathrm{C}$ until use.

\section{Primers and probes}

Before the experimental assays, an in silico test was performed to select primers and probes in order to detect any genotype of VHSV. With this in mind, a multiple sequence alignment was applied, using Clustal W, on a selection of strains from all genotypes of the virus (Table 1). Both $\mathrm{G}$ and $\mathrm{N}$ genes were subjected to analysis to find an optimum region to design 
Table 1. Strains of viral haemorrhagic septicaemia virus (VHSV), infectious haematopoietic necrosis virus (IHNV), and infectious pancreatic necrosis virus (IPNV) used in this study. 1: Strains employed in the in silico assays; 2: strains employed in the sensitivity assays; 3 : strains employed in the specificity assays

\begin{tabular}{|c|c|c|c|c|}
\hline & Isolate & Assay & Host species & GenBank accession no. \\
\hline \multicolumn{5}{|c|}{ VHSV strains (genotype) } \\
\hline I & DK-F1 & 3 & Oncorhynchus mykiss & \\
\hline \multirow[t]{6}{*}{ Ia } & Fr0771 & $1,2,3$ & Oncorhynchus mykiss & AJ233396 \\
\hline & OM13.01 & 3 & Oncorhynchus mykiss & \\
\hline & Ssp11.02 & 3 & Solea sp. & \\
\hline & STF180.01 & 3 & Salmo trutta fario & \\
\hline & SS19.01 & 3 & Salmo salar & \\
\hline & CP4370 & 3 & Chondrostoma polylepis & \\
\hline \multirow[t]{5}{*}{$\mathrm{Ib}$} & DK5p31 & 2,3 & Clupea harengus & \\
\hline & DK1p40 & 3 & Rhinonemus cimbrius & \\
\hline & DK1p12 & 3 & Clupea harengus & \\
\hline & DK4p37 & 1 & Micromesistius poutassou & FJ460590 \\
\hline & SE-SVA-1033 & 1 & Oncorhynchus mykiss & FJ460591 \\
\hline Id & NO-A163-68EG46 & 1 & Oncorhynchus mykiss & AB672619 \\
\hline $\mathrm{Ie}$ & GE-1.2. & 1 & Oncorhynchus mykiss & AB672617 \\
\hline \multirow[t]{5}{*}{ II } & DK1p49 & $1,2,3$ & Clupea harengus & KM244767 \\
\hline & DK1p52 & 1,3 & Sprattus sprattus & AB672621 \\
\hline & DK1p53 & 3 & Clupea harengus & \\
\hline & DK1p54 & 3 & Gadus morhua & \\
\hline & DK5p551 & 3 & Clupea harengus & \\
\hline \multirow[t]{8}{*}{ III } & GH40 & 1,3 & Reinhardtius hippoglossoides & KM244768 \\
\hline & FA281107 & 1 & Oncorhynchus mykiss & EU481506 \\
\hline & UK860/94 & 3 & Scophthalmus maximus & \\
\hline & SA2648 & 3 & Sparus aurata & \\
\hline & $\mathrm{SC} 2645$ & 3 & Oncorhynchus kisutch & \\
\hline & SM2705 & 3 & Scophthalmus maximus & \\
\hline & MLA98/6WH1 & 2,3 & Merlangius merlangus & \\
\hline & DK4p101 & 3 & Merlangius merlangus & \\
\hline \multirow[t]{5}{*}{ IVa } & US-Makah & $1,2,3$ & Oncorhynchus kisutch & X59241 \\
\hline & KRRV9822 & 1 & Paralichthys olivaceus & AB179621 \\
\hline & US93EB5 & 3 & Clupea sp. & \\
\hline & JP99Obama25 & 3 & Paralichthys olivaceus & \\
\hline & JF00EhiI & 1 & Paralichthys olivaceus & AB490792.1 \\
\hline \multirow[t]{2}{*}{$\mathrm{IVb}$} & MI03GL & 1 & Esox masquinongy & GQ385941 \\
\hline & Goby1-5 & $1,2,3$ & Neogobius sp. & $\mathrm{AB} 672615$ \\
\hline IVc & CA-NB-00-01 & 1 & Fundulus heteroclitus & EF079895 \\
\hline \multicolumn{5}{|c|}{ Non-specific reference strains } \\
\hline IHNV & WRAC & 1,3 & Oncorhynchus mykiss & AY442518 \\
\hline IHNV & LB91KI & 1 & Oncorhynchus nerka & AY438975 \\
\hline IHNV & River Butte 91 & 2,3 & & \\
\hline IHNV & Applegate River 93 & 2,3 & & \\
\hline IPNV & West Buxton & 3 & & \\
\hline
\end{tabular}

a universal set of primers and probe, and the best one, at least at a predictable level, was observed in a conserved sequence of the N gene. Primers VHSVTUsense (5'-CCG CGA GTT CGC YGA GCT TGT$\left.3^{\prime}\right)$ and VHSV-TUantisense (5'-GGR GCT CCT GAA GTT GCG GGC-3') were designed using the Allele ID 3.0 software (Premier Biosoft) to amplify a fragment of $163 \mathrm{bp}$ between positions 1149-1169 and 1311-1291 of the N gene of strain Fr0771 of VHSV (GenBank accession no. AJ233396). The same software was used to design the TaqMan probe TQMTU (5'-ATC AGG GAG GCG GCC AGA CAG
CA-3'). The probe, labelled at the $5^{\prime}$ end with the reporter molecule 6-carboxyfluorescein (FAM) and at the 3' end with the Black Hole Quencher (BHQ1), was ordered from Sigma.

\section{Reverse transcription}

The synthesis of cDNA from viral RNA was performed using Superscript III RT (Invitrogen). To this end, $9 \mu \mathrm{l}$ of extracted RNA were mixed with $2.5 \mathrm{ng}$ $\mathrm{\mu l}^{-1}$ of random primers and the mixture was incu- 
bated at $95^{\circ} \mathrm{C}$ for $5 \mathrm{~min}$ and on ice for at least $1 \mathrm{~min}$. A reverse transcription mixture containing $10 \mathrm{U}^{-1}$ of enzyme, $0.5 \mathrm{mM}$ dNTPs and 0.05M DTT in $1 \times$ first strand buffer was then added, and the final mixture was incubated at $25^{\circ} \mathrm{C}$ for $10 \mathrm{~min}$, followed by $50 \mathrm{~min}$ at $50^{\circ} \mathrm{C}$. The reaction was finally stopped by heating at $85^{\circ} \mathrm{C}$ for $5 \mathrm{~min}$.

\section{SYBR Green qPCR}

qPCR was performed using an iCycler iQ CFX96 ${ }^{\mathrm{TM}}$ Real Time System (Bio Rad). The reactions were carried out in a final volume of $20 \mu \mathrm{l}$ containing $100 \mathrm{nM}$ of each primer set and $2 \mu \mathrm{l}$ of $\mathrm{CDNA}$ in $\mathrm{iQ}^{\mathrm{TM}} \mathrm{SYBR}^{\circledR}$ Green Supermix (BioRad). Following an initial 2 min activation/denaturation step at $95^{\circ} \mathrm{C}$, the mixture was subjected to 40 cycles of amplification (denaturation for $15 \mathrm{~s}$ at $95^{\circ} \mathrm{C}$, annealing and extension for $30 \mathrm{~s}$ at $58^{\circ} \mathrm{C}$ ). Generation of PCR products was monitored after each extension step at $82^{\circ} \mathrm{C}$ by measuring the fluorescence of double-stranded DNA binding SYBR Green dye. In order to determine the melting temperatures $\left(T_{\mathrm{m}}\right)$ of the amplified products after SYBR Green qPCR, the temperature was raised from 58 to $95^{\circ} \mathrm{C}$ and the fluorescence detected during $10 \mathrm{~s}$ after each $0.2^{\circ} \mathrm{C}$. From each reaction, the threshold cycle value $(\mathrm{Ct})$ was established as the cycle number at which fluorescence was detectable over the threshold value calculated by the iCycler iQ software (BioRad) for cycles 2-10.

\section{TaqMan qPCR}

qPCR was performed using the KAPA PROBE FAST universal qPCR Kit (Kapa Biosystems). Mixtures of a total volume of $20 \mu$ l contained $2 \mu$ l of cDNA, $10 \mu$ of Kapa probe Fast Universal $2 \times$ qPCR Master Mix, $250 \mathrm{nM}$ of probe and $100 \mathrm{nM}$ of each primer. Following an initial 2 min activation/denaturation step at $95^{\circ} \mathrm{C}$, the mixture was subjected to 40 cycles of amplification (denaturation for $15 \mathrm{~s}$ at $95^{\circ} \mathrm{C}$, annealing and extension for $30 \mathrm{~s}$ at $58^{\circ} \mathrm{C}$ ) in an iCycler iQ CFX96 ${ }^{\mathrm{TM}}$ Real Time System (BioRad).

\section{Evaluation of analytical sensitivity}

The sensitivity of the diagnostic procedure was evaluated against different standards: titrated virus, RNA from crude virus, RNA from purified virus, plasmid DNA and in vitro transcribed RNA. Three repli- cates per assay and dilution (intra-run repeatability), and 3 different assays on 3 different days (inter-run reproducibility) were performed by workers with different levels of experience (with a minimum of $2 \mathrm{yr}$ of training). In order to evaluate the reliability of the standards, and consequently of the detection limit obtained, a standard curve for each set of data was generated and a regression line calculated for the logarithm of the number of copies and the corresponding $\mathrm{Ct}$ values. The parameters considered to evaluate the reliability of the curve were the coefficient of determination $\left(\mathrm{R}^{2}\right)$ and the amplification efficiency $(E)$ calculated from the formula $E=10^{-1 / S}-1$ (where $S$ is the slope of the linear fit).

Minimum detectable viral titre

To assess the minimum quantity of virus detectable by this qRT-PCR procedure, and to compare it with the sensitivity of the traditional method of isolation in cell culture, 1 reference strain from each genotype was tested: strain Fr0771 from genotype Ia, DK-5p31 from genotype Ib, DK-1p49 from genotype II, UKMLA98/6WH1 from genotype III and strains USMakah and Goby1-5 from genotypes IVa and IVb, respectively. For this assay, 10-fold dilutions of the corresponding virus were prepared and distributed into 2 aliquots: the first was subjected to qRT-PCR and the second to isolation in cell culture using monolayers of EPC cells.

\section{Detection limit using RNA from crude} and purified virus

Purification of virus was performed as previously described (Cutrín et al. 2009). Both crude and purified virus were subjected to total RNA extraction as described above. To prepare the RNA standards, the

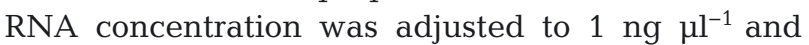
serial 10-fold dilutions were prepared down to 1 ag $\mu^{-1}$. All dilutions were subjected to qRT-PCR.

\section{Detection limit using plasmid DNA}

Specific primers for the nucleoprotein gene encompassing the regions corresponding to primer set VHS-TU (cm3a: CAG GCG TTG TCC GTG CTT CT; and N3b: CTA AAA GGC ACT CCC GTC TCA TAA) were designed to produce a fragment of $1049 \mathrm{bp}$ from the FR07/71 strain. After RT-PCR, the amplicon 
was purified and cloned into the pGEM-T Easy vector (Promega) under conditions recommended by the supplier, and individual clones were isolated. The cloned plasmid DNA was extracted and purified with the GeneJET ${ }^{\mathrm{TM}}$ Plasmid Miniprep kit (Fermentas). For quantification, the linearized plasmid and insert were run in an agarose gel $(2 \%)$ with Trackit ${ }^{\mathrm{TM}} 1 \mathrm{~Kb}$ Plus DNA Ladder (Invitrogen) as reference. Densitometry was applied on the gel, and quantification was performed with General-Purpose Analysis Software FUJI FILM Multi Gauge version 3.0 (Fuji Photo Film). The mass of a single pDNA molecule was calculated using the formula $\gamma=\mathrm{n} / \mathrm{N} \times \mathrm{GL} \times \mathrm{NcMw}$, where $\gamma$ is the amount (in $\mathrm{g}$ ), $\mathrm{n}$ is the number of DNA molecules (copies), $\mathrm{N}$ is the Avogadro number $\left(6.022 \times 10^{23}\right)$, GL is the size of the recombinant plasmid $(4064 \mathrm{bp}$, with $3015 \mathrm{bp}$ corresponding to pGEM-T and $1049 \mathrm{bp}$ to the insert), and NcMw is the average molecular weight of each pair of nucleotides (estimated at $660 \mathrm{~g}$ $\mathrm{mol}^{-1}$ ). The concentration of the resulting plasmid solution was around $200 \mathrm{ng}^{-1} \mathrm{l}^{-1}$ (corresponding to $4.49 \times 10^{10}$ copies $\mathrm{\mu l}^{-1}$ ), and 10 -fold serial dilutions were prepared down to $1 \mathrm{ag}^{-1} \mathrm{l}^{-1}$ and subjected to qPCR.

\section{Detection limit using an RNA transcript}

Approximately $400 \mathrm{ng}$ of the previously constructed plasmid were linearized by digestion with $S a l I$ in a $20 \mu l$ reaction according to the enzyme manufacturer's instructions (FastDigest ${ }^{\circledR}$ Sall, Fermentas). The reaction was incubated for $15 \mathrm{~min}$ at $37^{\circ} \mathrm{C}$, followed by heat inactivation at $65^{\circ} \mathrm{C}$ for $10 \mathrm{~min}$. The linearized DNA was purified using the QIAquick PCR purification kit (Qiagen), according to the manufacturer's protocol. RNA transcripts were generated using the MEGAscript ${ }^{\circledR}$ Kit (Ambion). Approximately $0.5 \mu \mathrm{g}$ of linearized plasmid were added to $20 \mu \mathrm{l}$ of transcription reaction, containing $5 \mathrm{mM}$ of each ribonucleotide and $2 \mu \mathrm{l}$ of enzyme mix in $10 x$ Reaction buffer. The transcription reaction was incubated at $37^{\circ} \mathrm{C}$ for $4 \mathrm{~h}$. A DNase treatment was conducted using Ambion's Turbo DNase Kit for $30 \mathrm{~min}$ at $37^{\circ} \mathrm{C}$. To recover the RNA, the MEGAclearTM Kit (Ambion) was used according to the manufacturer's instructions, and RNA transcripts were quantified using a Nanodrop ND-100. Copy numbers were then determined based on the expected N-gene transcript molecular weight, based on the formula $\gamma=\mathrm{n} / \mathrm{N} \times$ GL $\times \mathrm{NcMw}$, where $\gamma$ is the amount (in $\mathrm{g}$ ) of viral RNA, $\mathrm{n}$ is the number of genomic RNA molecules (copies), $\mathrm{N}$ is the Avogadro number $\left(6.022 \times 10^{23}\right)$, GL is the transcript length in nucleotides (1153 nt), and $\mathrm{NcMw}$ is the average molecular weight of a single nucleotide (estimated at $340.5 \mathrm{Da}$ ). From the formula, $1 \mu \mathrm{g}$ of $\mathrm{N}$ transcript was deduced to contain $1.53 \times$ $10^{12}$ copies. Serial dilutions were prepared down to $1 \mathrm{ag}^{-1}$ and subjected to real-time RT-PCR.

\section{Evaluation of specificity}

To test specificity, a panel of 26 VHSV isolates covering the 4 genotypes was used (Table 1). In addition, 3 strains of IHNV type 1 (WRAC, River Butte 91 and Applegate River 93), a virus closely related to VHSV, and 1 strain of infectious pancreatic necrosis virus (IPNV; West Buxton) were included as negative controls. Additionally, to confirm the specificity of the amplified products, 3 methods were used: (1) in the SYBR Green assays, the melting temperature $\left(T_{\mathrm{m}}\right)$ was automatically calculated by the equipment, and the value obtained compared with that deduced from the sequence of the expected fragment; (2) the size of the amplicons was verified by electrophoresis in $1.5 \%$ agarose gels; (3) the amplified fragments were subjected to sequence analysis with the $\mathrm{CEQ}^{\mathrm{TM}}$ Dye Terminator Cycle Sequencing (DTCS) Quick Start Kit (Beckman Coulter), after extraction of the DNA from the agarose gel with the DNA Gel Extraction Kit (Millipore).

\section{Evaluation of repeatability and reproducibility}

Repeatability (defined as the precision determined under conditions where the same methods and equipment are used by the same operator to make measurements on identical specimens) and reproducibility (the precision determined under conditions where the same methods but different equipment or days are used by different operators) were determined by the intra-assay and inter-assay (respectively) coefficients of variation (CV). Intra-run $\mathrm{CV}$ was determined with $\mathrm{Ct}$ values from 3 replicates of each reaction, and the inter-run $\mathrm{CV}$ was calculated with $\mathrm{Ct}$ values collected from 3 different reactions (runs) of the same samples performed on nonconsecutive days.

\section{Validation of the procedure for quantification}

Once the reliability of the standard curves was demonstrated from the repeatability and repro- 
ducibility, the determination coefficients and the efficiency values as described above, a general equation was obtained for each type of standard tested (viral titre, RNA from crude and from purified virus, RNA transcript and plasmid) and for each of both chemistries assayed (SYBR Green and TaqMan probes). Those equations were of the type $C t=S C+$ $I$, where $I$ is the intercept value, $S$ is the curve slope, $C$ is the number of copies assayed (as decimal logarithm), and $C t$ is the corresponding $\mathrm{Ct}$ value obtained.

In a diagnostic procedure, however, the focus is to determine the number of RNA copies corresponding to a Ct value observed after amplification of an RNA sample. Therefore, the initial equations were transformed by the isolation of the $c$ variable into $c=S^{\prime} C t$ $+I^{\prime}$, where $S^{\prime}$ and $I^{\prime}$ are the recalculated slope and intercept values.

To determine whether 2 or more curves were similar, the slopes and intersection were compared by an F-test, using the SGPP5 software (Graph Pad Prism). If the $p$-value is small $(p<0.05)$ for both parameters, the idea that differences are due to random sampling can be rejected and therefore the curves are different; if differences are only demonstrated for the intersections, the curves are assumed to be parallel. To determine whether the use of different chemis- tries implies significant differences in the standard curves, the data yielding both equations for each type were compared by a $t$-test using Mann-Whitney with SGPP5; as before, significant differences were defined with $\mathrm{p}$-values under 0.05 .

\section{RESULTS}

\section{Selection of primers and probe}

To design a qRT-PCR assay for detection of any genotype of VHSV, the first step was the in silico selection of the best set of primers and probe, which were selected in a conserved region identified within the $\mathrm{N}$ gene of VHSV on the basis of 15 available sequences as shown in Fig. 1. Neither the primers nor the probe showed significant homology with the IHNV sequences tested as a negative control. In addition, NCBI resources and Allele ID 7.60 software (Premier Biosoft International) were used to ensure that this set of primers/probe did not recognise other related viruses or could amplify unwanted targets, e.g. in the fish genome (data not shown).

Finally, in order to determine their optimal concentration in the reaction mixtures, preliminary qRTPCR reactions were performed with different con-

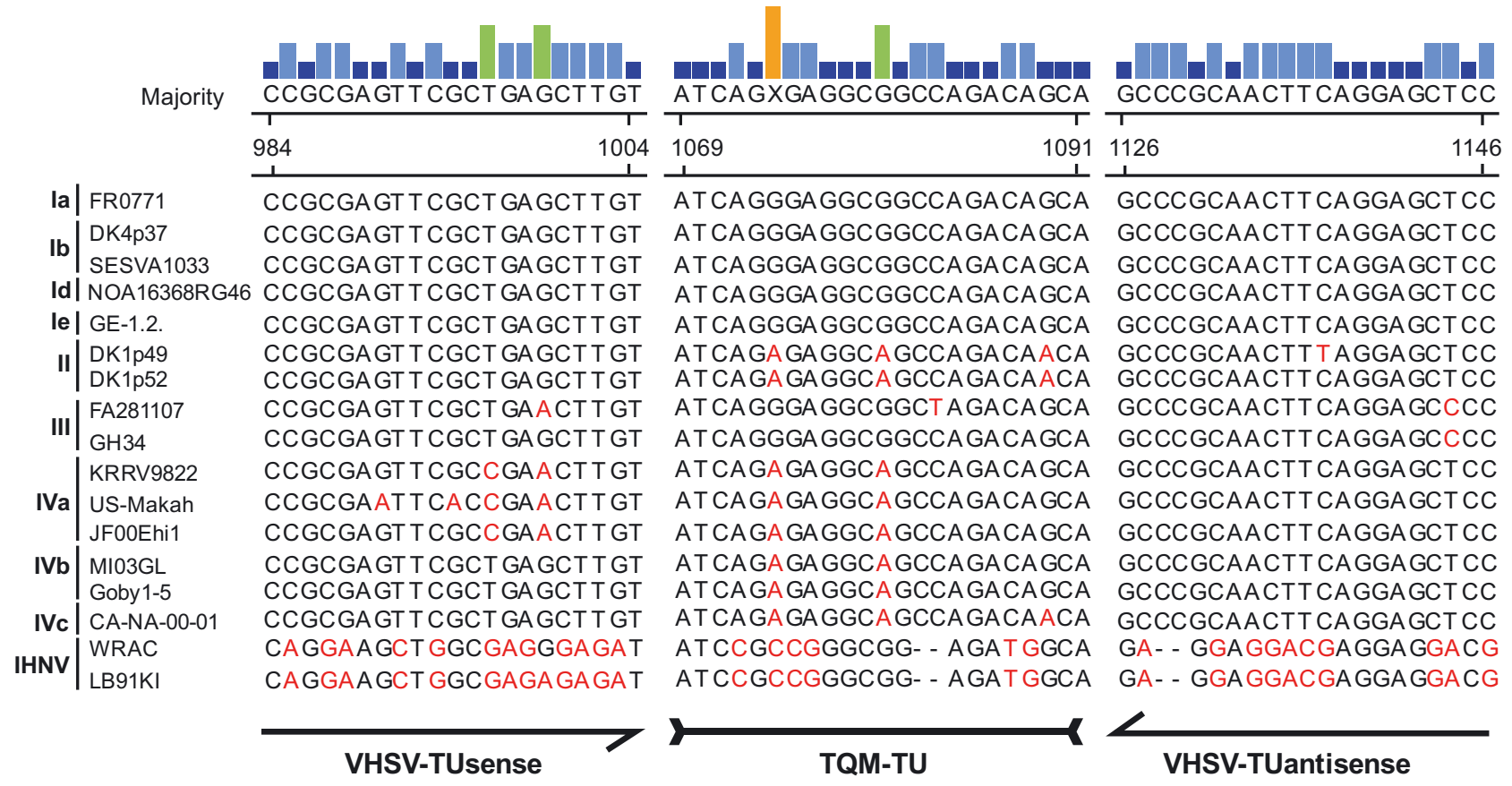

Fig. 1. Design of TaqMan probe and primers. Multialignment of partial sequences of the N-gene of different viral haemorrhagic septicaemia virus (VHSV) isolates showing the positions and sequences of 1 set of primers (VHSV-TU) and probe (TQM-TU) assayed. Accession numbers are shown in Table 1 
centrations of primers and probe between 125 and $300 \mathrm{nM}$, and the results showed $250 \mathrm{nM}$ to be the optimal concentration for both chemicals assayed in terms of $\mathrm{Ct}$ values and level of fluorescence (data not shown).

\section{Analytical specificity}

The specificity of the procedure was tested against a panel of 26 isolates, covering all VHSV genotypes, as well as several negative controls including IHNV and IPNV strains (Table 1). The procedure provided amplification with all of the VHSV strains tested, independently from their genotype, with an average Ct value of $15.32 \pm 2.08$ (Fig. 2A); in addition, no false positives were recorded when using nonspecific viruses as a negative control. To confirm the specificity of the amplicons, the melting point $\left(T_{\mathrm{m}}\right)$ was calculated automatically, and the observed mean values resembled those expected from the in silico theoretical calculation: $87.0 \pm 0.1^{\circ} \mathrm{C}$ for Genotype I isolates $\left(87 . \pm 0.1\right.$ in silico theoretical $\left.T_{\mathrm{m}}\right), 85.4 \pm 0.3^{\circ} \mathrm{C}$ for genotype II isolates (85.2 theoretical $T_{\mathrm{m}}$ ), $86.5 \pm$ $0.2^{\circ} \mathrm{C}$ for genotype III $\left(86.7 \pm 0.2\right.$ theoretical $\left.T_{\mathrm{m}}\right)$ and $85.9 \pm 0.2^{\circ} \mathrm{C}\left(86.2 \pm 0.2\right.$ theoretical $\left.T_{\mathrm{m}}\right)$ for genotype IV (Fig. 2B). The amplification products were subjected to agarose gel electrophoresis. As shown in Fig. 2C, the expected $163 \mathrm{bp}$ PCR product was obtained in all cases (except with the non-specific negative control viruses), and sequencing confirmed their specificity.
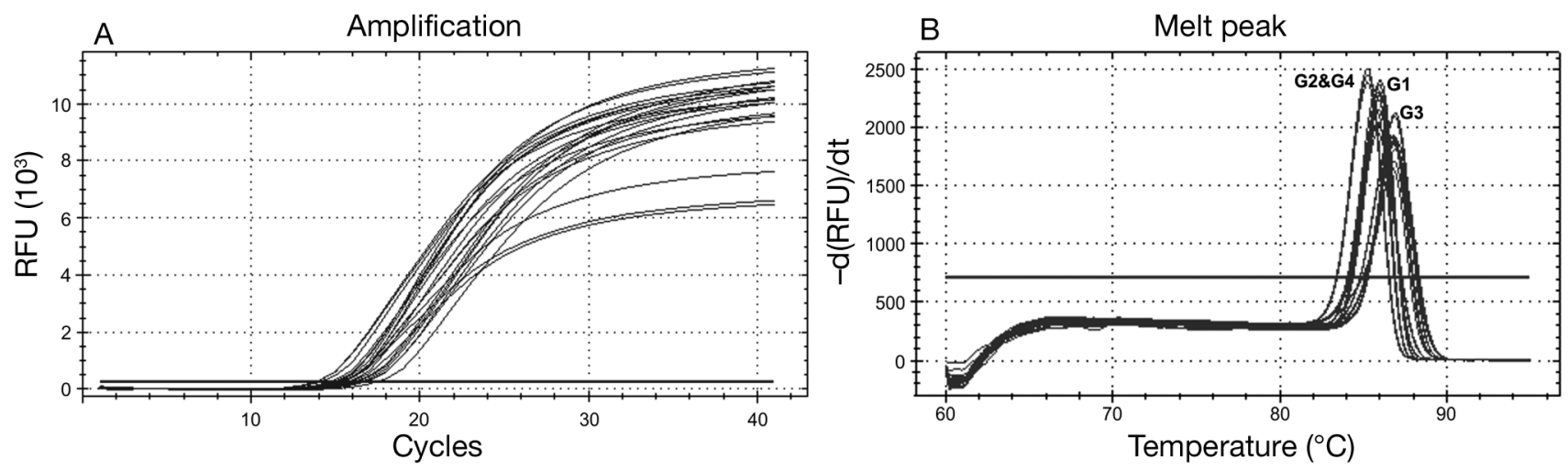

C
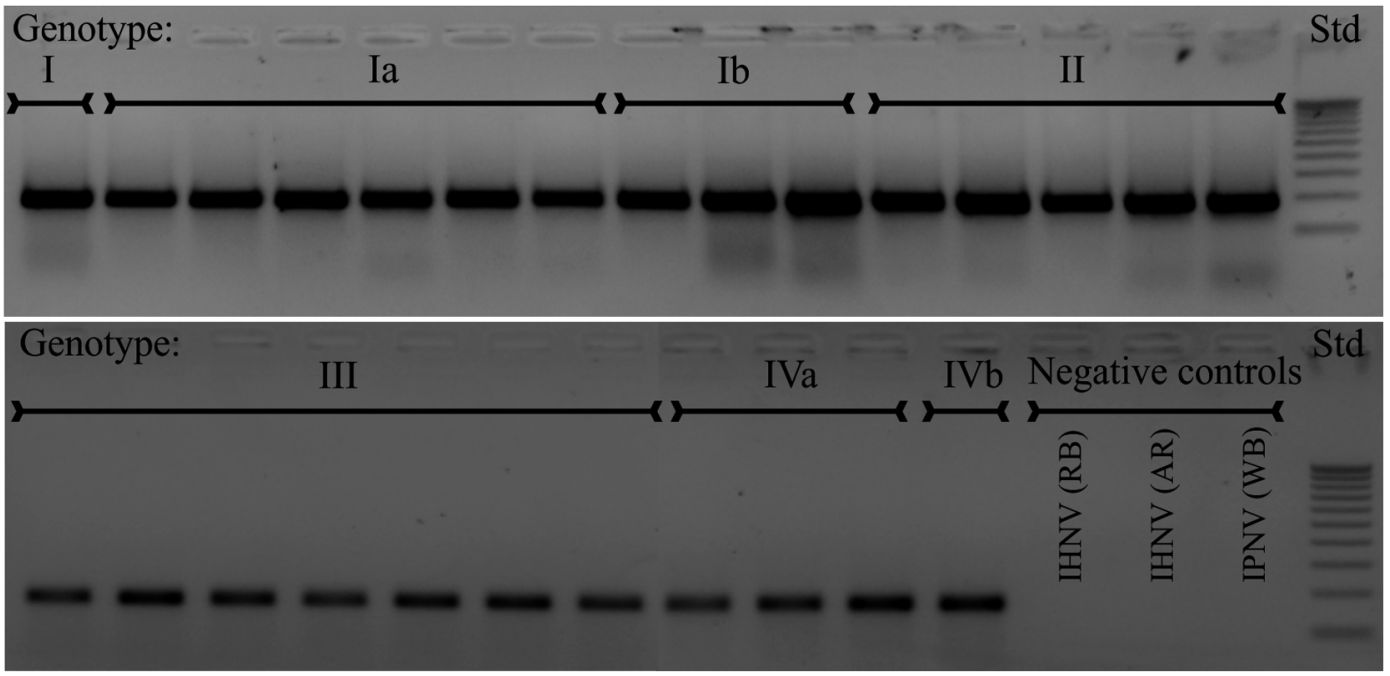

Fig. 2. Development of the SYBR Green qRT-PCR assay (RFU: relative fluorescence units), with primers TU-VHSV for the detection of viral haemorrhagic septicaemia virus (VHSV) isolates belonging to 4 genotypes. (A) Representative amplification profiles. (B) Representative melting temperature $\left(T_{\mathrm{m}}\right)$ analysis routinely performed on qRT-PCR products. (C) Visualization of the amplification products after agarose gel electrophoresis. For all VHSV strains, the visualized band corresponded to an amplification fragment of the expected size of $163 \mathrm{bp}$. Two strains of infectious haematopoietic necrosis virus (IHNV: River Butte 91 and Applegate River93) and 1 strain of infectious pancreatic necrosis virus (IPNV: West Buxton) were used as negative controls. Std: 100 bp DNA ladder (10 fragments ranging from 100 to $1000 \mathrm{bp}$ in 100 bp increments; Genecraft) 


\section{Analytical sensitivity}

Minimum detectable viral titre

A comparison of the limit of detection (LD), in terms of minimum detectable viral titre, between qRT-PCR and isolation in cell culture was performed, and the results are shown in Table 2. As observed, the LD was 2 logs lower with qRT-PCR than with cell culture isolation (where all 3 replicates were positive) for most of the reference strains. No differences between the chemistries (SYBR Green and TaqMan probe) were observed, ensuring an LD, in terms of viral titre, of around $10^{0} \mathrm{TCID}_{5} \mathrm{ml}^{-1}$ with most genotypes (close to $10^{-1}$ with DK1p49 and Goby1-5).
The qRT-PCR results from these assays were also used to evaluate the reliability of this kind of standard curve. The results shown in Table 2 correspond to the mean $( \pm \mathrm{SD})$ from the 3 runs performed on different days. Previously, the analysis of the CV values from the 3 replicates of each run revealed a high level of repeatability, obtaining $\mathrm{CV}$ values from 0.1 to 1.4 (data not shown). Reproducibility is deduced from the data shown in the table, which provide $C V$ values between 0.1 and 2.4. Linear regression was applied to the data, and the standard curves with both SYBR Green and TaqMan chemistries are shown in Fig. 3. All the standard curves showed high $\mathrm{R}^{2}$ values, ranging between 0.990 and 0.995, and efficiencies $(E)$ from $104 \%$ (slope $=-3.221)$ to $95 \%($ slope $=-3.442)$.

Table 2. Comparison of the limit of detection (in terms of viral titre) of viral haemorrhagic septicaemia virus (VHSV) between qRT-PCR and cell culture isolation. CC: viral detection by isolation in epithelioma papulosum cyprini (EPC) cells from serial dilution of crude virus. Dil: 10 -fold serial dilutions were performed to obtain the indicated viral titres (in TCID $_{50} \mathrm{ml}^{-1}$ ). The number of pluses indicates the number of positives among the 3 replicates (dilutions showing positive in the 3 replicates yielded the same result in the 3 runs). qRT-PCR/SYBR: viral detection by SYBR Green qRT-PCR using primers VHSV-TU; qRT-PCR/TQM: viral detection by qRT-PCR using primers VHSV-TU and TaqMan probe TQM-TU. Values shown are the threshold cycle value $(\mathrm{Ct}) \pm \mathrm{SD}$ of 3 repetitions. Bold font indicates that only 1 of 3 replicates was amplified

\begin{tabular}{|c|c|c|c|c|c|c|c|c|}
\hline \multicolumn{9}{|l|}{ Fr0771 } \\
\hline Dil & $10^{6}$ & $10^{5}$ & $10^{4}$ & $10^{3}$ & $10^{2}$ & $10^{1}$ & $10^{0}$ & $10^{-1}$ \\
\hline $\mathrm{CC}$ & +++ & +++ & +++ & +++ & +++ & + & + & \\
\hline qRT-PCR/SYBR & $14.2 \pm 0.06$ & $18.5 \pm 0.13$ & $22.1 \pm 0.06$ & $25.9 \pm 0.03$ & $28.6 \pm 0.22$ & $31.5 \pm 0.16$ & $34.2 \pm 0.31$ & \\
\hline qRT-PCR/TQM & $14.4 \pm 0.08$ & $18.6 \pm 0.12$ & $22.2 \pm 0.04$ & $25.9 \pm 0.05$ & $28.6 \pm 0.19$ & $31.2 \pm 0.11$ & $34.2 \pm 0.19$ & $38.1 \pm 22.0$ \\
\hline \multicolumn{9}{|l|}{ DK5p31 } \\
\hline Dil & $10^{6}$ & $10^{5}$ & $10^{4}$ & $10^{3}$ & $10^{2}$ & $10^{1}$ & $10^{0}$ & \\
\hline $\mathrm{CC}$ & +++ & +++ & +++ & +++ & +++ & + & + & \\
\hline qRT-PCR/SYBR & $14.4 \pm 0.13$ & $18.6 \pm 0.14$ & $22.3 \pm 0.09$ & $25.5 \pm 0.11$ & $28.4 \pm 0.09$ & $31.3 \pm 0.08$ & $34.2 \pm 0.30$ & \\
\hline qRT-PCR/TQM & $14.8 \pm 0.05$ & $18.5 \pm 0.45$ & $22.3 \pm 0.40$ & $25.9 \pm 0.10$ & $28.2 \pm 0.03$ & $31.2 \pm 0.05$ & $34.5 \pm 0.15$ & \\
\hline \multicolumn{9}{|l|}{ DK1p49 } \\
\hline Dil & $5.6 \times 10^{5}$ & $5.6 \times 10^{4}$ & $5.6 \times 10^{3}$ & $5.6 \times 10^{2}$ & $5.6 \times 10^{1}$ & $5.6 \times 10^{0}$ & $5.6 \times 10^{-1}$ & \\
\hline $\mathrm{CC}$ & +++ & +++ & +++ & +++ & +++ & + & & \\
\hline qRT-PCR/SYBR & $15.1 \pm 0.06$ & $19.1 \pm 0.07$ & $23.5 \pm 0.10$ & $26.5 \pm 0.11$ & $29.5 \pm 0.06$ & $32.9 \pm 0.53$ & $35.6 \pm 0.23$ & \\
\hline qRT-PCR/TQM & $15.1 \pm 0.10$ & $19.0 \pm 0.11$ & $23.2 \pm 0.46$ & $26.4 \pm 0.09$ & $29.6 \pm 0.05$ & $32.5 \pm 0.10$ & $35.5 \pm 0.29$ & \\
\hline \multicolumn{9}{|l|}{ MLA98/6WH1 } \\
\hline Dil & $10^{5}$ & $10^{4}$ & $10^{3}$ & $10^{2}$ & $10^{1}$ & $10^{0}$ & $10^{-1}$ & \\
\hline $\mathrm{CC}$ & +++ & +++ & +++ & +++ & + & + & & \\
\hline qRT-PCR/SYBR & $18.6 \pm 0.14$ & $22.6 \pm 0.44$ & $25.2 \pm 0.21$ & $28.4 \pm 0.46$ & $31.6 \pm 0.23$ & $34.2 \pm 0.07$ & & \\
\hline qRT-PCR/TQM & $18.6 \pm 0.15$ & $22.3 \pm 0.38$ & $25.4 \pm 0.13$ & $28.5 \pm 0.29$ & $31.5 \pm 0.44$ & $34.6 \pm 0.17$ & & \\
\hline \multicolumn{9}{|l|}{ US-Makah } \\
\hline Dil & $5.6 \times 10^{5}$ & $5.6 \times 10^{4}$ & $5.6 \times 10^{3}$ & $5.6 \times 10^{2}$ & $5.6 \times 10^{1}$ & $5.6 \times 10^{0}$ & $5.6 \times 10^{-1}$ & \\
\hline $\mathrm{CC}$ & +++ & +++ & +++ & +++ & +++ & + & & \\
\hline qRT-PCR/SYBR & $15.1 \pm 0.23$ & $19.4 \pm 0.12$ & $22.7 \pm 0.15$ & $25.2 \pm 0.07$ & $28.8 \pm 0.36$ & $32.9 \pm 0.32$ & & \\
\hline qRT-PCR/TQM & $15.2 \pm 0.33$ & $19.3 \pm 0.29$ & $22.5 \pm 0.25$ & $25.3 \pm 0.42$ & $28.4 \pm 0.20$ & $33.1 \pm 0.19$ & $36.2 \pm 22.0$ & \\
\hline \multicolumn{9}{|l|}{ Goby1-5 } \\
\hline Dil & $5.6 \times 10^{5}$ & $5.6 \times 10^{4}$ & $5.6 \times 10^{3}$ & $5.6 \times 10^{2}$ & $5.6 \times 10^{1}$ & $5.6 \times 10^{0}$ & $5.6 \times 10^{-1}$ & \\
\hline $\mathrm{CC}$ & +++ & +++ & +++ & +++ & +++ & + & & \\
\hline qRT-PCR/SYBR & $15.2 \pm 0.08$ & $19.0 \pm 0.43$ & $23.1 \pm 0.14$ & $25.5 \pm 0.13$ & $29.4 \pm 0.25$ & $33.3 \pm 0.32$ & $35.4 \pm 0.38$ & \\
\hline qRT-PCR/TQM & $15.0 \pm 0.20$ & $19.5 \pm 0.35$ & $23.0 \pm 0.29$ & $25.5 \pm 0.18$ & $29.2 \pm 0.14$ & $33.3 \pm 0.34$ & $35.4 \pm 0.43$ & \\
\hline
\end{tabular}




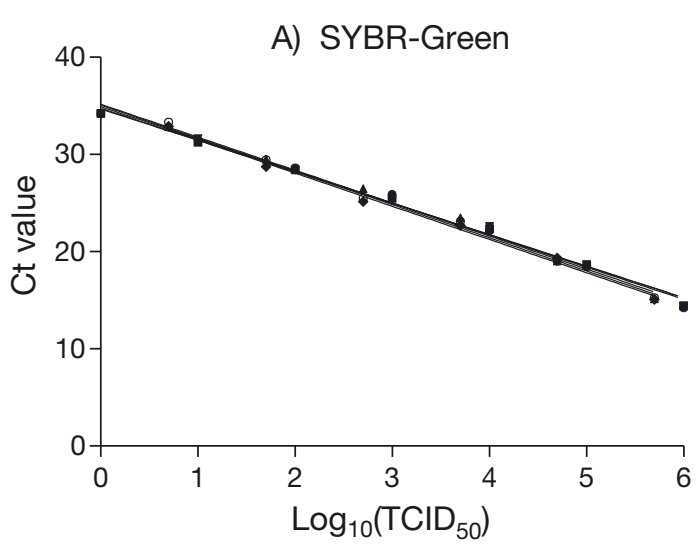

$\rightarrow \operatorname{FR0771}\left(S=-3.303 \pm 0.06848 ; R^{2}=0.9919\right)$
$-\operatorname{DK} 5 p 31\left(S=-3.239 \pm 0.05717 ; R^{2}=0.9941\right)$
$\rightarrow \operatorname{DK} 1 p 49\left(S=-3.390 \pm 0.06281 ; R^{2}=0.9935\right)$
$\rightarrow \operatorname{MLA98} / 6$ WH1 $\left(S=-3.248 \pm 0.06381 ; R^{2}=0.9927\right)$
$\rightarrow$ US-Makah $\left(S=-3.418 \pm 0.06807 ; R^{2}=0.9937\right)$
General equation: $y=-3.3296 x+34.910\left(R^{2}=0.9943\right)$

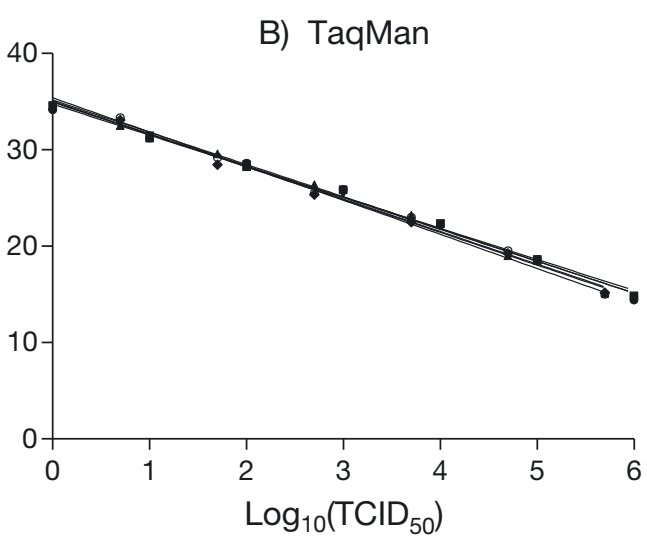

$\rightarrow$ FR0771 $\left(S=-3.341 \pm 0.08946 ; R^{2}=0.9900\right)$
$\rightarrow$ DK5p31 $\left(S=-3.221 \pm 0.05484 ; R^{2}=0.9945\right)$
$\rightarrow$ DK1p49 $\left(S=-3.376 \pm 0.05815 ; R^{2}=0.9944\right)$
$\rightarrow$ MLA98/6WH1 $\left(S=-3.299 \pm 0.05328 ; R^{2}=0.9951\right)$
$\rightarrow-$ US-Makah $\left(S=-3.442 \pm 0.08692 ; R^{2}=0.9899\right)$
$\rightarrow-G o b y 1-5\left(S=-3.394 \pm 0.06545 ; R^{2}=0.9930\right)$

General equation: $y=-3.3544 x+35.0241\left(R^{2}=0.9937\right)$

Fig. 3. Standard curves of minimum detectable viral titre. RNA extracted from serial dilutions of crude virus from all genotypes of viral haemorrhagic septicaemia virus (VHSV) was used as a standard for detection by (A) SYBR Green and (B) TaqMan RTreal time PCR. Graphs show linear regression data from the 3 replicates and 3 repetitions $(S$ : slope expressed as mean \pm SD; $\mathrm{R}^{2}$ : average determination coefficient). The general equation is a single equation summarizing the results obtained from 3 replicates and 3 repetitions using all the strains assayed. See 'Materials and methods' for further details

In addition, the comparison of the slopes and intercepts (within each type of chemistry) revealed no significant differences $(p>0.05)$ between strains. Therefore, a unique equation was calculated summarizing the results obtained from the 3 replicas and 3 repetitions with all strains assayed, providing slopes of $-3.329(E=99 \%)$ with SYBR Green, and -3.354 $(E=98 \%)$ with TaqMan probes, and $\mathrm{R}^{2}$ values of 0.9943 and 0.9937 , respectively.

\section{LD of viral RNA from crude and purified virus}

Sensitivity was also evaluated with RNA extracted from purified virus (strain Fr0771, belonging to genotype Ia). As shown in Table 3, the LD reached $100 \mathrm{ag}$ (16 genome copies), at a Ct value between 35 and 36, with both chemistries. The data shown in Table 3 correspond to the mean $( \pm \mathrm{SD})$ from the 3 repetitions performed on different days. Previously, the analysis of the CV values from the 3 replicates revealed a high level of repeatability, obtaining $\mathrm{CV}$ values from 0.3 to 1.3 with SYBR Green, and from 0.1 to 1.2 with TaqMan (data not shown). The CV values corresponding to reproducibility were extremely low (from 0.43 to
$1.49 \%$ with SYBR Green and from 0.60 to $1.24 \%$ with TaqMan; Table 1). The standard curves showed high $\mathrm{R}^{2}$ levels (from 0.997 to 0.998 ) and efficiency values (between 109\% and 104\%, as determined from the slopes; Fig. 4). The slopes and intercepts were compared, and no significant differences were observed ( $p$ > 0.05). Therefore, a unique equation, with high $\mathrm{R}^{2}$ (0.998 and 0.997, SYBR Green and TaqMan, respectively) and $E(104 \%$ and $108 \%)$ values, was calculated for each chemistry from the 3 replicates and repetitions (Fig. 4).

This assay was also performed using RNA extracted from crude virus of a representative strain of each genotype and, as shown in Table 3, the procedure yielded similar results with both chemistries, achieving the detection of viral RNA to a minimum concentration of $1 \mathrm{fg}^{-1}$ (corresponding to approximately 160 genome copies), and without differences between genotypes. All replicates yielded similar results, with low variations in Ct values and low coefficients of variation (under 2.98), corresponding to high repeatability (data not shown). As shown in the table, inter-run CV values (reproducibility) were also low $(0.69-3.02 \%$ with SYBR Green; $0.14-3.12 \%$ with TaqMan). Linear regression was applied to the data 


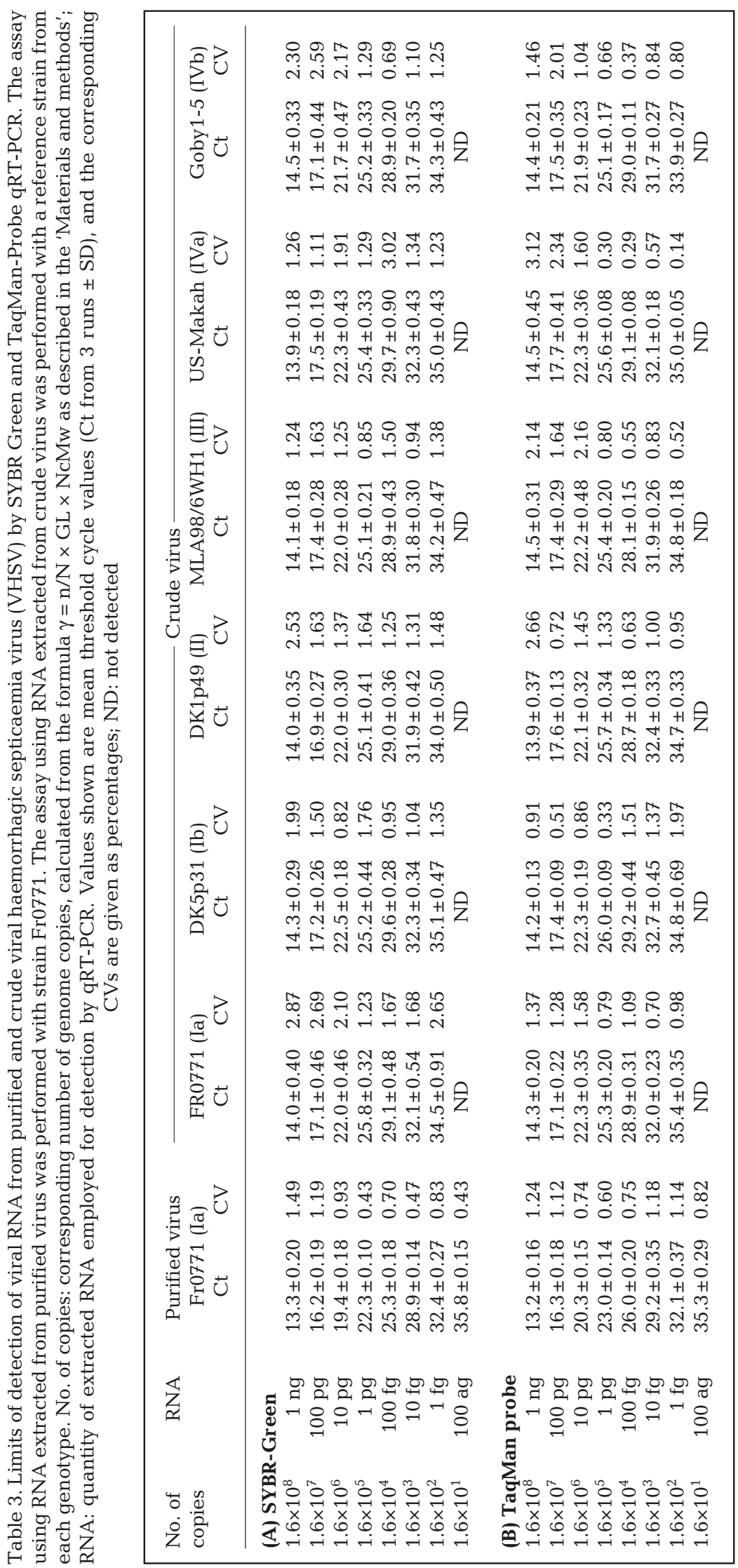

(Fig. 5), and the standard curves for all the strains showed $R^{2}$ values between 0.991 and 0.997 . The slopes and intercepts were compared with the F-test, revealing no significant differences $(\mathrm{p}>$ 0.05 ) between strains. A unique equation for each chemistry was therefore calculated applying a new linear regression to all of the data, which yielded standard curves with high $\mathrm{R}^{2}$ values (0.991 and 0.993, with SYBR Green and TaqMan, respectively) and efficiencies $(E=93.4 \%, S=-3.492$ with SYBR Green; $E=94.1 \%, S=-3.475$ with TaqMan).

\section{LD using plasmid DNA as a standard}

A fourth method to evaluate the sensitivity used a cloned cDNA corresponding to a fragment of the $\mathrm{N}$ gene of strain Fr0771 as a standard. Ten-fold dilutions were prepared from $2.25 \times 10^{8}$ to $2.25 \times 10^{-1}$ copies, and the LD was determined by both SYBR Green and TaqMan real-time PCR. Although the viral genome could occasionally be detected at the lowest concentration, in 1 out of 3 replicates (Table 4), the detection limit was established at $10 \mathrm{ag}^{\mathrm{al}} \mathrm{l}^{-1}$ of recombinant plasmid (corresponding to around 2 copies) with both SYBR Green and TaqMan, since the maximum reliability of the method (detection in all replicates) is required. Another remarkable result comes from the visualization of the amplification curves, since their kinetics seem to be proportionally related to the initial quantity of template (Fig. 6A,B); this was demonstrated by the high values of the corresponding determination coefficients $\left(\mathrm{R}^{2}\right)$ (Fig. 6C,D).

Intra-assay $\mathrm{CV}$ values (repeatability) were under 5 in all cases, and interassay CV (reproducibility) ranged from 0.15 to $4.47 \%$ with SYBR Green, and from 0.50 to $2.09 \%$ with TaqMan (Table 4). Linear regression was applied to the data from the 3 runs, yielding $\mathrm{R}^{2}$ values between 0.990 and 0.997 , and efficiencies (deduced from the slopes) be- 


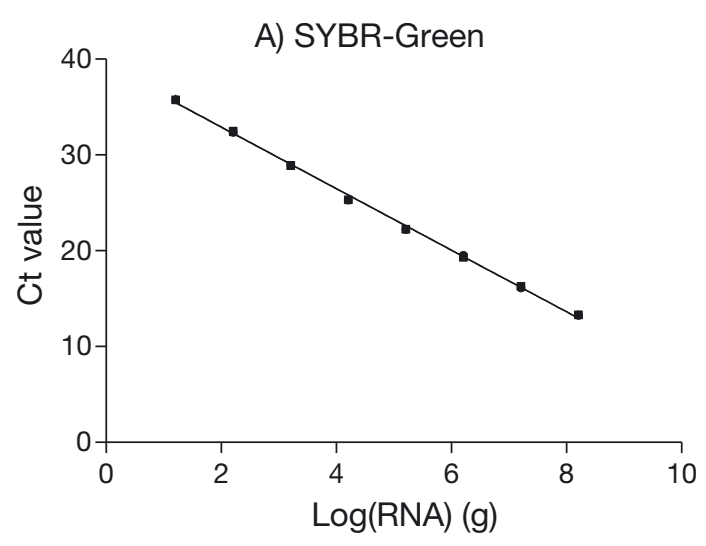

$\rightarrow-\operatorname{Run} 1\left(S=-3.213 \pm 0.02912 ; R^{2}=0.9982\right)$
$\hookrightarrow$ Run $2\left(S=-3.212 \pm 0.03252 ; R^{2}=0.9977\right)$
$\longleftarrow$ Run $3\left(S=-3.215 \pm 0.03018 ; R^{2}=0.9981\right)$

General equation: $y=-3.2129 x+39.335\left(R^{2}=0.9980\right)$

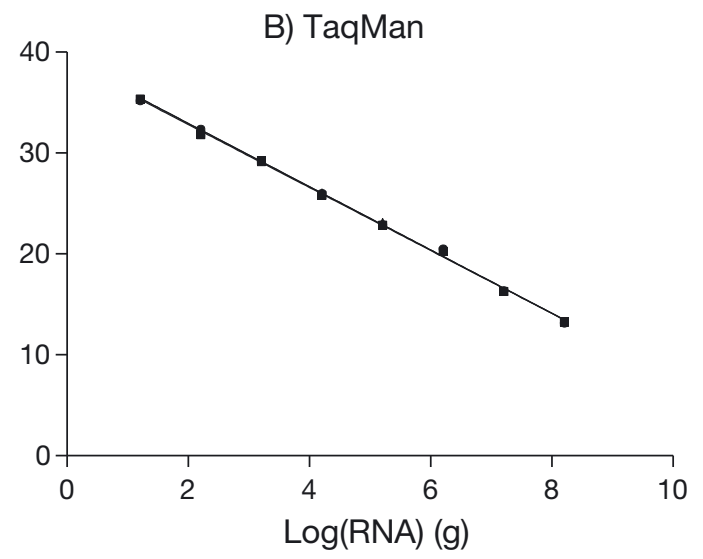

$\multimap$ Run $1\left(S=-3.136 \pm 0.03201 ; R^{2}=0.9977\right)$
$-\operatorname{Run} 2\left(S=-3.120 \pm 0.03531 ; R^{2}=0.9972\right)$
$\longleftarrow \operatorname{Run} 3\left(S=-3.134 \pm 0.03027 ; R^{2}=0.9980\right)$

General equation: $y=-3.1302 x+39.1627\left(R^{2}=0.997\right)$

Fig. 4. Standard curves with purified virus. Serial dilutions of viral RNA extracted from purified viral haemorrhagic septicaemia virus (VHSV, strain FR0771) were used as a standard for detection by (A) SYBR Green and (B) TaqMan real-time

RT-PCR. Graphs show 3 curves corresponding to 3 runs on different days (3 replicates per run). Equations as in Fig. 3

A) SYBR-Green

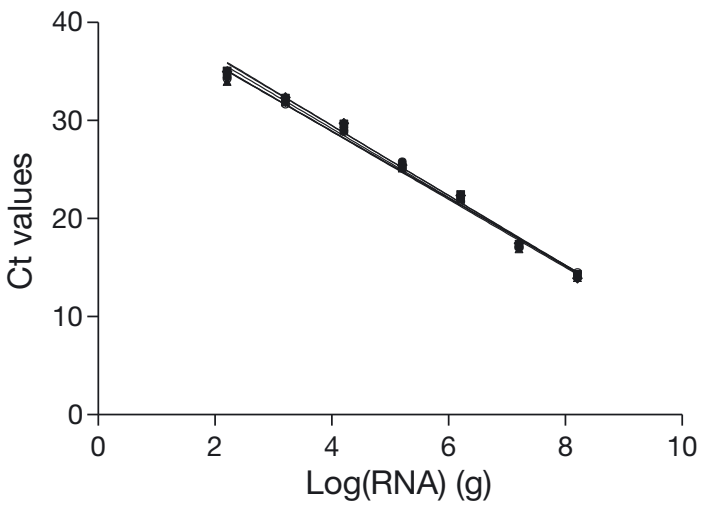

$\rightarrow \operatorname{FR0771}\left(S=-3.515 \pm 0.05543 ; R^{2}=0.9915\right)$
$\rightarrow \operatorname{DK} 5 p 31\left(S=-3.553 \pm 0.04579 ; R^{2}=0.9920\right)$
$\leftarrow \operatorname{DK} 1 p 49\left(S=-3.464 \pm 0.05171 ; R^{2}=09912\right)$
$\rightarrow \operatorname{MLA} 98 / 6 W H 1\left(S=-3.422 \pm 0.04176 ; R^{2}=0.9920\right)$
$\rightarrow$ US-Makah $\left(S=-3.583 \pm 0.05048 ; R^{2}=0,9950\right)$
$\rightarrow$ Goby1-5 $\left(S=-3.416 \pm 0.04117 ; R^{2}=0.9920\right)$

General equation: $y=-3.4923 x+43.121\left(R^{2}=0.9910\right)$
B) TaqMan

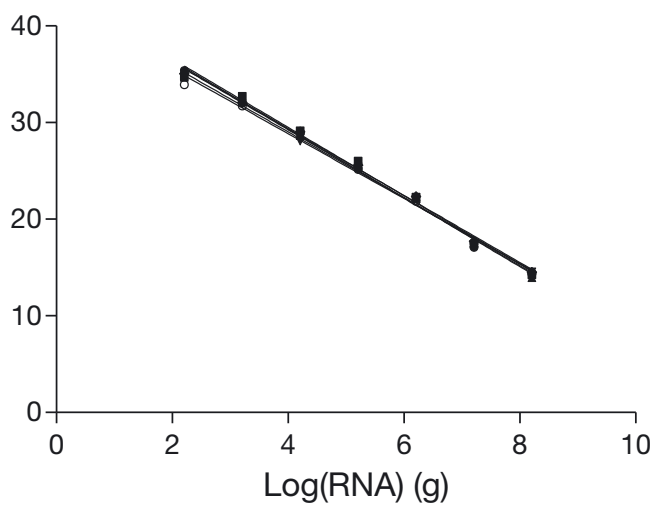

$\rightarrow \operatorname{FR0771}\left(S=-3.560 \pm 0.06035 ; R^{2}=0.9946\right)$
$\rightarrow \operatorname{DK5p31}\left(S=-3.540 \pm 0.08358 ; R^{2}=0.9945\right)$
$\leftarrow \operatorname{DK} 1 p 49\left(S=-3.516 \pm 0.07028 ; R^{2}=0.9935\right)$
$\rightarrow \operatorname{MLA98/6WH1}\left(S=-3.415 \pm 0.05859 ; R^{2}=0.9964\right)$
$\rightarrow$ US-Makah $\left(S=-3.464 \pm 0.05713 ; R^{2}=0.9949\right)$
$\rightarrow$ Goby1-5 $\left(S=-3.358 \pm 0.07045 ; R^{2}=0.9917\right)$

General equation: $y=-3.4754 x+43.130\left(R^{2}=0.9930\right)$

Fig. 5. Standard curves with crude virus. Serial dilutions of viral RNA extracted from crude virus of all genotypes of viral haemorrhagic septicaemia virus (VHSV) were used as a standard for detection by (A) SYBR Green and (B) TaqMan real-time RT-PCR. Equations as in Fig. 3

tween 93.4 and $104.7 \%$ (Fig. 6C,D). In addition, no significant differences between slopes and intercepts were observed ( $p>0.05)$; therefore, a linear regression was applied to all of the data to obtain a new single standard curve for each chemistry, showing in both cases high R ${ }^{2}$ (0.999 and 0.996, with SYBR Green and TaqMan, respectively) and efficiencies of 96.8 and $104.9 \%$ (Fig. 6C,D). 
Table 4. Limit of detection of viral haemorrhagic septicaemia virus (VHSV) using plasmid DNA as standard. Details and abbreviations as in Table $3 .{ }^{\mathrm{a}}$ One of the 3 replicates was amplified

\begin{tabular}{|c|c|c|c|c|c|c|c|c|c|}
\hline \multirow{2}{*}{$\begin{array}{l}\text { No. of } \\
\text { copies }\end{array}$} & \multirow[t]{2}{*}{ RNA } & \multicolumn{2}{|c|}{ - Run1 } & - Run2 & \multirow[b]{2}{*}{$\mathrm{CV}$} & - Run3 & \multirow[b]{2}{*}{$\mathrm{CV}$} & \multirow{2}{*}{$\overline{\mathrm{Ct}}^{\text {Inter-run }}$} & \multirow{2}{*}{$\mathrm{CV}$} \\
\hline & & $\mathrm{Ct}$ & $\mathrm{CV}$ & $\mathrm{Ct}$ & & $\mathrm{Ct}$ & & & \\
\hline \multicolumn{10}{|c|}{ (A) SYBR-Green } \\
\hline $2.25 \times 10^{8}$ & $1 \mathrm{ng}$ & $8.5 \pm 0.36$ & 4.25 & $8.3 \pm 0.06$ & 0.72 & $8.1 \pm 0.13$ & 1.61 & $8.3 \pm 0.26$ & 3.11 \\
\hline $2.25 \times 10^{7}$ & $100 \mathrm{pg}$ & $13.2 \pm 0.43$ & 3.26 & $13.3 \pm 0.44$ & 3.30 & $12.4 \pm 0.35$ & 2.83 & $13.0 \pm 0.58$ & 4.47 \\
\hline $2.25 \times 10^{6}$ & $10 \mathrm{pg}$ & $16.3 \pm 0.07$ & 0.42 & $16.9 \pm 0.07$ & 0.41 & $15.6 \pm 0.09$ & 0.58 & $16.3 \pm 0.61$ & 3.77 \\
\hline $2.25 \times 10^{5}$ & $1 \mathrm{pg}$ & $19.7 \pm 0.08$ & 0.40 & $20.5 \pm 0.27$ & 1.32 & $18.8 \pm 0.14$ & 0.74 & $19.7 \pm 0.72$ & 3.66 \\
\hline $2.25 \times 10^{4}$ & $100 \mathrm{fg}$ & $23.3 \pm 0.43$ & 1.84 & $23.8 \pm 0.11$ & 0.46 & $23.0 \pm 0.14$ & 0.61 & $23.4 \pm 0.44$ & $\begin{array}{l}.00 \\
1.9\end{array}$ \\
\hline $2.25 \times 10^{3}$ & $10 \mathrm{fg}$ & $26.6 \pm 0.07$ & 0.26 & $27.3 \pm 0.12$ & 0.44 & $26.5 \pm 0.04$ & 0.15 & $26.8 \pm 0.35$ & 1.32 \\
\hline $2.25 \times 10^{2}$ & $1 \mathrm{fg}$ & $29.9 \pm 0.19$ & 0.63 & $30.8 \pm 0.42$ & 1.36 & $30.5 \pm 0.46$ & 1.51 & $30.4 \pm 0.53$ & 1.74 \\
\hline $2.25 \times 10^{1}$ & $100 \mathrm{ag}$ & $33.3 \pm 0.57$ & 1.71 & $33.3 \pm 0.20$ & 0.60 & $33.0 \pm 0.29$ & 0.88 & $33.2 \pm 0.37$ & 1.1 \\
\hline $2.25 \times 10^{0}$ & $10 \mathrm{ag}$ & $35.2 \pm 0.90$ & 2.55 & $35.2 \pm 0.37$ & 1.05 & $35.6 \pm 0.21$ & 0.59 & $35.3 \pm 0.53$ & 1.49 \\
\hline $2.25 \times 10^{-1}$ & $1 \mathrm{ag}$ & ND & & ND & & ND & & & \\
\hline \multicolumn{10}{|c|}{ (B) TaqMan probe } \\
\hline $2.25 \times 10^{6}$ & $10 \mathrm{pg}$ & $17.4 \pm 0.07$ & 0.38 & $17.7 \pm 0.09$ & 0.49 & $17.5 \pm 0.09$ & 0.51 & $17.5 \pm 0.19$ & 1.08 \\
\hline $2.25 \times 10^{5}$ & $1 \mathrm{pg}$ & $20.2 \pm 0.08$ & 0.38 & $20.4 \pm 0.08$ & 0.39 & $20.3 \pm 0.07$ & 0.34 & $20.3 \pm 0.16$ & 0.79 \\
\hline $2.25 \times 10^{4}$ & $100 \mathrm{fg}$ & $22.8 \pm 0.43$ & 1.88 & $23.0 \pm 0.41$ & 1.77 & $22.8 \pm 0.31$ & 0.13 & $22.9 \pm 0.41$ & 1.81 \\
\hline $2.25 \times 10^{3}$ & $10 \mathrm{fg}$ & $26.9 \pm 0.08$ & 0.30 & $27.2 \pm 0.06$ & 0.22 & $27.1 \pm 0.10$ & 0.36 & $27.0 \pm 0.17$ & 0.63 \\
\hline $2.25 \times 10^{2}$ & $1 \mathrm{fg}$ & $30.2 \pm 0.08$ & 0.25 & $30.5 \pm 0.10$ & 0.32 & $30.4 \pm 0.10$ & 0.32 & $30.4 \pm 0.18$ & 0.59 \\
\hline $2.25 \times 10^{1}$ & $100 \mathrm{ag}$ & $33.9 \pm 0.09$ & 0.27 & $34.2 \pm 0.07$ & 0.21 & $34.1 \pm 0.12$ & 0.35 & $34.1 \pm 0.17$ & 0.50 \\
\hline $2.25 \times 10^{0}$ & $10 \mathrm{ag}$ & $35.9 \pm 0.64$ & 1.77 & $36.8 \pm 0.70$ & 1.91 & $36.9 \pm 0.50$ & 1.3 & $36.4 \pm 0.76$ & 2.09 \\
\hline $2.25 \times 10^{-1}$ & $1 \mathrm{ag}$ & $38.8^{\mathrm{a}}$ & & $39.1^{\mathrm{a}}$ & & $39.2^{\mathrm{a}}$ & & $39.1 \pm 19.54^{\mathrm{a}}$ & 49.90 \\
\hline
\end{tabular}
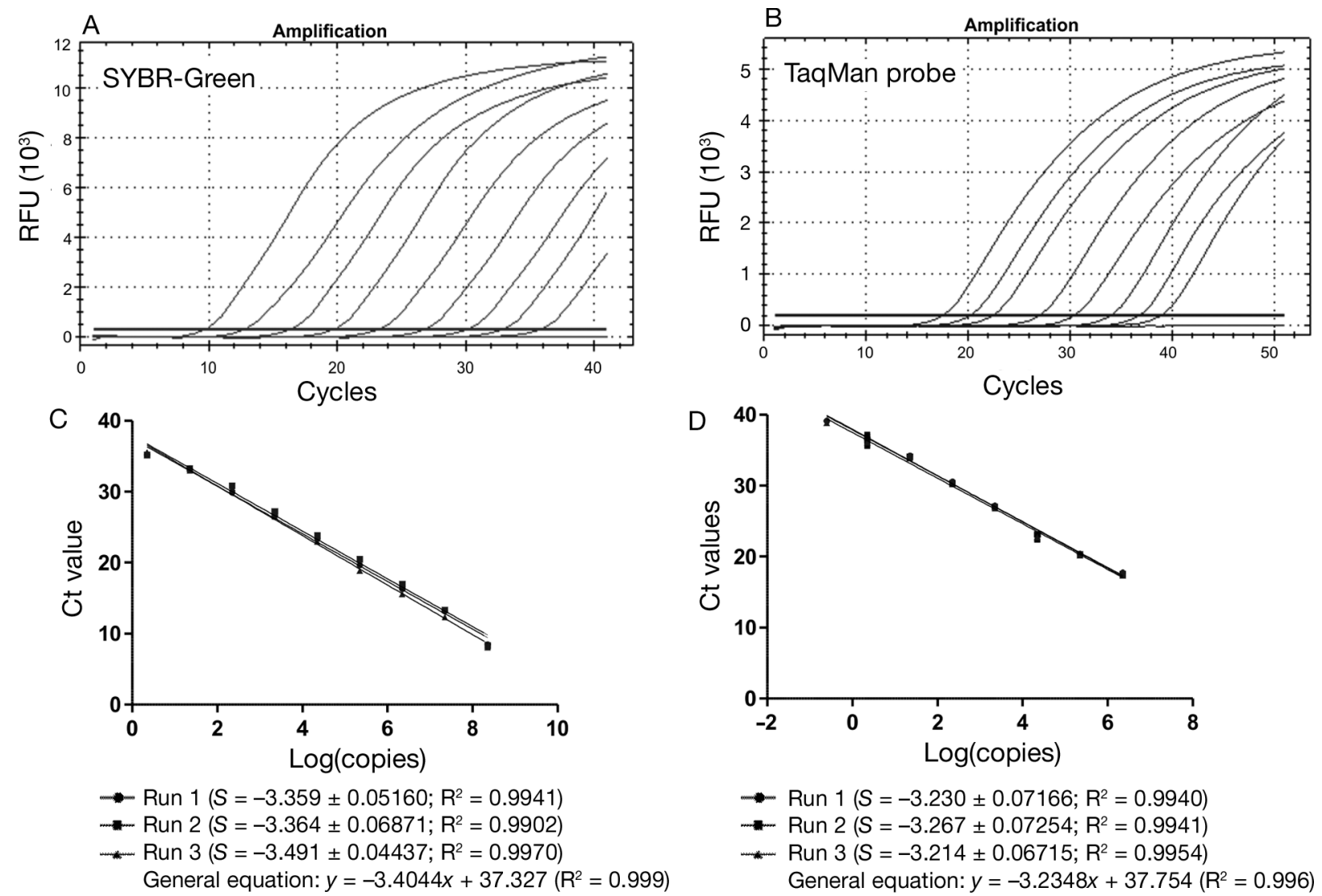

Fig. 6. Evaluation of analytical sensitivity using plasmid DNA as a standard. Ten-fold dilutions (from $2.2 \times 10^{8}$ to $2.2 \times 10^{-1}$ copies) of a cloned cDNA corresponding to a fragment of the N gene of viral haemorrhagic septicaemia virus (VHSV) strain Fr0771 were subjected to amplification by real-time PCR using $(A, C)$ SYBR Green or $(B, D)$ TaqMan probes. Three replicates per run and 3 runs (repetitions on different days) were performed. $(A, B)$ Typical amplification curves for the serial concentrations of template; $(C, D)$ linear regressions for the 3 runs. The general equation is a single equation summarizing the results 
Table 5. Limit of detection of viral haemorrhagic septicaemia virus (VHSV) using RNA transcript as standard. Details and abbreviations as in Table 3

\begin{tabular}{|c|c|c|c|c|c|c|c|c|c|}
\hline \multirow{2}{*}{$\begin{array}{l}\text { No. of } \\
\text { copies }\end{array}$} & \multirow[t]{2}{*}{ RNA } & \multicolumn{2}{|c|}{ - Run1- } & \multicolumn{2}{|c|}{$\longrightarrow$ Run2 } & \multicolumn{2}{|c|}{ Run3 } & \multicolumn{2}{|c|}{ - Inter-run } \\
\hline & & $\mathrm{Ct}$ & $\mathrm{CV}$ & $\mathrm{Ct}$ & $\mathrm{CV}$ & $\mathrm{Ct}$ & $\mathrm{CV}$ & $\mathrm{Ct}$ & $\mathrm{CV}$ \\
\hline \multicolumn{10}{|c|}{ (A) SYBR-Green } \\
\hline $1.53 \times 10^{8}$ & $100 \mathrm{pg}$ & $12.8 \pm 0.37$ & 2.89 & $12.7 \pm 0.25$ & 1.92 & $13.2 \pm 0.17$ & 1.32 & $12.9 \pm 0.30$ & 2.36 \\
\hline $1.53 \times 10^{7}$ & $10 \mathrm{pg}$ & $16.2 \pm 0.38$ & 2.37 & $16.6 \pm 0.45$ & 2.73 & $16.3 \pm 0.35$ & 2.15 & $16.4 \pm 0.39$ & 2.35 \\
\hline $1.53 \times 10^{6}$ & $1 \mathrm{pg}$ & $19.9 \pm 0.55$ & 2.73 & $19.9 \pm 0.23$ & 1.16 & $20.4 \pm 0.21$ & 1.01 & $20.1 \pm 0.38$ & 1.90 \\
\hline $1.53 \times 10^{5}$ & $100 \mathrm{fg}$ & $24.0 \pm 0.63$ & 2.65 & $23.9 \pm 0.10$ & 0.42 & $24.5 \pm 0.11$ & 0.44 & $24.1 \pm 0.42$ & 1.74 \\
\hline $1.53 \times 10^{4}$ & $10 \mathrm{fg}$ & $27.0 \pm 0.44$ & 1.63 & $26.9 \pm 0.53$ & 1.97 & $26.4 \pm 0.13$ & 0.50 & $26.8 \pm 0.45$ & 1.70 \\
\hline $1.53 \times 10^{3}$ & $1 \mathrm{fg}$ & $31.1 \pm 0.26$ & 0.84 & $30.6 \pm 0.30$ & 0.98 & $30.9 \pm 0.40$ & 1.28 & $30.9 \pm 0.36$ & 1.17 \\
\hline $1.53 \times 10^{2}$ & $100 \mathrm{ag}$ & $34.4 \pm 0.28$ & 0.81 & $34.7 \pm 0.19$ & 0.54 & $34.8 \pm 0.41$ & 1.18 & $34.6 \pm 0.31$ & 0.90 \\
\hline $1.53 \times 10^{1}$ & $10 \mathrm{ag}$ & $37.2 \pm 0.16$ & 0.42 & $37.4 \pm 0.20$ & 0.52 & $37.0 \pm 0.33$ & 0.88 & $37.2 \pm 0.25$ & 0.68 \\
\hline $1.53 \times 10^{0}$ & $1 \mathrm{ag}$ & ND & & ND & & ND & & & \\
\hline \multicolumn{10}{|c|}{ (B) TaqMan probe } \\
\hline $1.53 \times 10^{8}$ & $100 \mathrm{pg}$ & $12.8 \pm 0.36$ & 2.79 & $11.6 \pm 0.43$ & 3.71 & $12.2 \pm 0.42$ & 3.45 & $12.2 \pm 0.62$ & 4.88 \\
\hline $1.53 \times 10^{7}$ & $10 \mathrm{pg}$ & $16.5 \pm 0.32$ & 1.92 & $17.1 \pm 0.68$ & 3.99 & $17.6 \pm 0.19$ & 1.08 & $17.1 \pm 0.60$ & 3.54 \\
\hline $1.53 \times 10^{6}$ & $1 \mathrm{pg}$ & $20.2 \pm 0.07$ & 0.35 & $19.6 \pm 0.33$ & 1.67 & $19.5 \pm 0.31$ & 1.57 & $19.8 \pm 0.43$ & 2.18 \\
\hline $1.53 \times 10^{5}$ & $100 \mathrm{fg}$ & $24.2 \pm 0.32$ & 1.33 & $23.9 \pm 0.31$ & 1.28 & $23.9 \pm 0.52$ & 2.20 & $24.0 \pm 0.37$ & 1.55 \\
\hline $1.53 \times 10^{4}$ & $10 \mathrm{fg}$ & $26.9 \pm 0.30$ & 1.11 & $26.6 \pm 0.43$ & 1.62 & $26.6 \pm 0.36$ & 1.34 & $26.7 \pm 0.36$ & 1.34 \\
\hline $1.53 \times 10^{3}$ & $1 \mathrm{fg}$ & $31.6 \pm 0.31$ & 0.98 & $31.4 \pm 0.21$ & 0.67 & $31.4 \pm 0.13$ & 0.41 & $31.4 \pm 0.22$ & 0.70 \\
\hline $1.53 \times 10^{2}$ & $100 \mathrm{ag}$ & $34.3 \pm 0.28$ & 0.82 & $34.1 \pm 0.27$ & 0.81 & $33.7 \pm 0.43$ & 1.28 & $34.0 \pm 0.40$ & 1.16 \\
\hline $1.53 \times 10^{1}$ & $10 \mathrm{ag}$ & $36.4 \pm 0.94$ & 2.57 & $36.6 \pm 0.11$ & 0.31 & $36.4 \pm 0.56$ & 1.53 & $36.5 \pm 0.55$ & 1.52 \\
\hline $1.53 \times 10^{0}$ & $1 \mathrm{ag}$ & ND & & ND & & ND & & & \\
\hline
\end{tabular}

\section{LD using RNA transcript as a standard}

An RNA transcript was constructed based on the same sequence used for the plasmid DNA. Tenfold serial dilutions (from $100 \mathrm{pg}^{-1} \mathrm{l}^{-1}$ to $1 \mathrm{ag}^{-1} \mathrm{l}^{-1}$, corresponding to $1.53 \times 10^{8}$ to $1.53 \times 10^{0}$ copies) were subjected to amplification by SYBR Green and TaqMan real-time RT-PCR, and the results are shown in Table 5 and Fig. 7. Detection of RNA transcript was achieved to a minimum concentration of $10 \mathrm{ag} \mathrm{hl}^{-1}$ (around 15 RNA copies) with both procedures. The intra-run CV values (repeatability) were below $2.9 \%$ with SYBR Green and $4.0 \%$ with TaqMan, and inter-run values (reproducibility) were below 2.4 and $4.9 \%$, respectively (Table 5). As with pDNA, using RNA transcript as a standard, the amplification curves seemed to be proportionally distributed according to the initial quantity of template (Fig. $7 \mathrm{~A}, \mathrm{~B}$ ), which was demonstrated by the high $\mathrm{R}^{2}$ values observed (Fig. 7C,D). In addition, no significant differences ( $p>0.05$ ) were observed between the slopes and intersections of the different runs. Linear regression applied to data from the 3 replicates and runs yielded standard curves with high $\mathrm{R}^{2}$ (0.998 and 0.995, with SYBR Green and TaqMan, respectively) and efficiency values (92.3 and $94.1 \%$, respectively; Fig. $7 \mathrm{C}, \mathrm{D})$.

\section{Comparison of the standards for quantification}

Once a single curve for each standard was obtained, and their reliability demonstrated, the next step was to evaluate whether significant differences were observed between both chemistries. To this end, a Mann-Whitney $t$-test was applied, demonstrating no significant differences $(p>0.05)$ between the equations of both chemistries, with any of the standards tested. Therefore, a unique equation for each standard was constructed using all available data from both chemistries.

To be used for quantification, those equations (of the type $C t=S C+I$ ) were transformed to $C=S^{\prime} C t+I^{\prime}$ (as described in 'Materials and methods: Validation of the procedure ...'), and the corresponding curves are shown in Fig. 8. Estimation of the quantity of virus clearly depended on the type of standard used as a reference, with the following scale (from lower to higher values): TCID, pDNA, purified virus, RNA transcript and crude virus. In addition, a certain parallelism appeared to exist among most of the curves, except with purified virus as a standard, which intersects (at low Ct values or high copy numbers) with the one corresponding to RNA transcript. To statistically determine which of those curves were truly parallel, the slopes of each pair of 

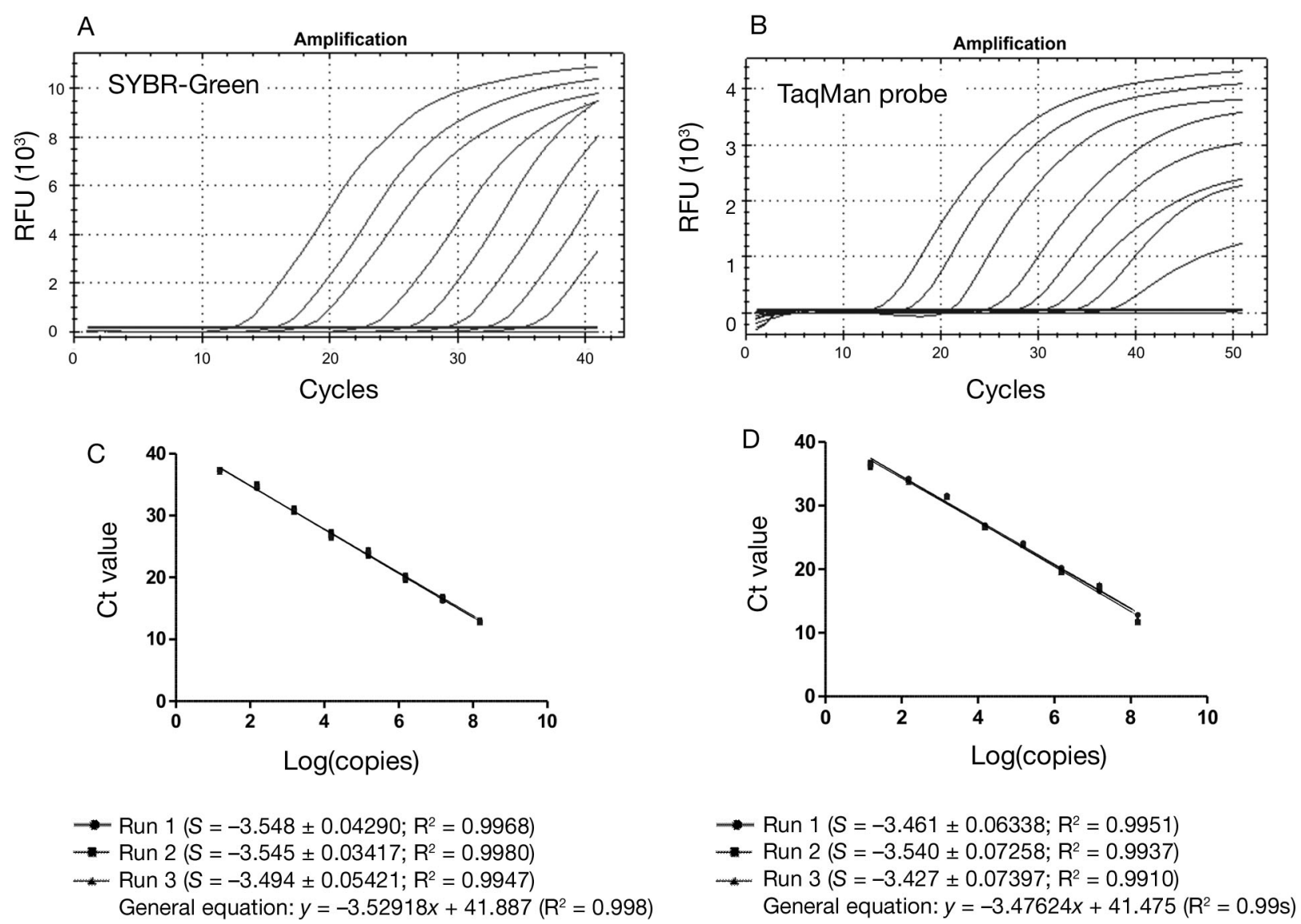

Fig. 7. Evaluation of analytical sensitivity using transcript RNA as a standard. Ten-fold dilutions (from $1.5 \times 10^{8}$ to $1.5 \times 10^{0}$ copies) of the transcript were subjected to amplification by real-time PCR using $(\mathrm{A}, \mathrm{C}) \mathrm{SYBR}$ Green or (B,D) TaqMan probes.

Details as in Fig. 6

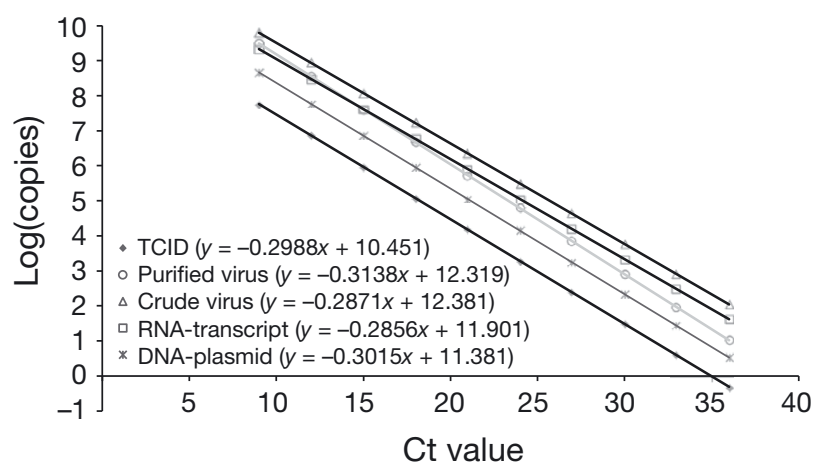

Fig. 8. Standard curves for viral quantification of viral haemorrhagic septicaemia virus (VHSV) using different types of template as standard

curves were compared and, in all cases, including pairs with the equation with purified virus, $\mathrm{p}$ was $>0.05$, demonstrating that all curves were parallel. After this surprising result, and to confirm that a unique conversion factor could be established between standards, the conversion factors ( $\mathrm{CF}$; comparing the expected number of copies from each pair of equations) between each set of 2 standard curves were calculated for $\mathrm{Ct}$ values between 9 and 36 , and, as shown in Table 6, the ranges of CF values were in all cases under 1 logarithm of difference. Therefore, the statistical average $\mathrm{CF}$ is shown as the reference for comparison between standards of quantification.

\section{DISCUSSION}

At present, real-time PCR technology is replacing traditional PCR, not only because of its higher reliability in terms of sensitivity and specificity, but also because it provides quick and simple processing and interpretation of results (regardless of the type of chemistry used: SYBR Green or TaqMan probes), and allows relative or absolute quantification of the 
Table 6. Mean conversion factors (CF) between each set of 2 standard curves (for threshold cycle values 9-36). Ranges of CF are given in parentheses

\begin{tabular}{|lcccc|}
\hline & Transcript & Purified virus & Plasmid & TCID \\
\hline Crude virus & 2.4 & 4.5 & 18.9 & 138 \\
& $(2.31-2.53)$ & $(1.7-9.1)$ & $(11.6-28.6)$ & $(94-194)$ \\
Transcript & 1 & 0.7 & 7.9 & 57 \\
& & $(0.2-1.4)$ & $(4.6-12.3)$ & $(37-84)$ \\
Purified virus & & 1 & 4.7 & 35 \\
& & & $(3.1-6.7)$ & $(21-54)$ \\
Plasmid & & & 1 & 7.4 \\
& & & & $(6.8-8.0)$ \\
\hline
\end{tabular}

assayed (in the form of crude virus); however, they obtained $\mathrm{Ct}$ values ranging from 15.04 to 38.66 (21.83 \pm 5.98), much higher that the Ct values observed in the similar experiment in our study $(15.32 \pm 2.08)$. Pierce et al. (2013) tested the specificity of their procedure on 25 strains of the 4 genotypes, with positive results in all cases; unfortunately, they did not provide information on the $\mathrm{Ct}$ values, which is important data in order to have an idea of the efficiency of the method for each type of strain.

template, which provides relevant information in a diagnosis. Therefore, the aim of the present study was to design and validate an qRT-PCR procedure for the diagnosis of VHSV of any genotype, which could be additionally and simultaneously employed to quantify the viral load.

Cutrín et al. (2009) reported a reliable multiplex real-time RT-PCR procedure for the diagnosis of VHSV, but it needed 2 sets of primers to ensure the detection of strains from the 4 genotypes and subtypes. Matejusova et al. (2008) designed a procedure with a single set of primers, which they called 'universal'; however, it was only tested on European strains. Therefore, in the present study, we decided to find a unique and truly universal set of primers and probe, and with this in mind, an in silico assessment was carried out on VHSV strains from different genotypes and subtypes, and the selection was performed in a consensus sequence targeting the $\mathrm{N}$ gene.

The in vitro evaluation of the primers (TU-VHSV), performed on 26 reference strains $(10,5,7$ and 4 strains from genotypes I, II, III and IV, respectively), demonstrated that they ensured detection of any type of strain, yielding amplicons of the correct size and sequence and, moreover, yielding the expected Tm values in the melting curves. No unspecific amplifications were observed with either unrelated or related viruses. Other studies have described the development of real-time RT-PCR for the diagnosis of this virus (Chico et al. 2006, Liu et al. 2008, Matejusova et al. 2008, Cutrín et al. 2009, Hope et al. 2010, Garver et al. 2011, Jonstrup et al. 2013, Pierce et al. 2013), but the detection of strains from all genotypes was not always ensured, or the procedure was not tested on a significant number of strains from each genotype. Two studies reported the testing of a procedure on a number of strains similar to that in the present study. Garver et al. (2011) demonstrated that the procedure they proposed ensured detection of all strains
As expected, the LD obtained was different depending on the type of reference employed to assess the sensitivity of the procedure (Table 7). In terms of minimum detectable viral titre, although some strains were detectable at a titre of $10^{-1} \mathrm{TCID}_{50} \mathrm{ml}^{-1}$, the LD was established at $10^{\circ}$, since it ensures the detection of any type of strain (at a Ct around 36), and a dynamic range of 8 orders of magnitude. This LD improves that reported by Jonstrup et al. (2013), who obtained an LD (in BF-2 cells) of $10^{1}$ to $10^{2}$ $\mathrm{TCID}_{50} \mathrm{ml}^{-1}$, and at least equals that reported by Hope et al. (2010). Furthermore, in our study, the LD is 100 times lower than that obtained with the traditional cell culture isolation, which is consistent with the results of both reports.

Using pDNA as the standard, the LD was quite similar to that of TCID: 2 copies (equivalent to 2 particles), at a $\mathrm{Ct}$ value of 37 . The effective dynamic range was of 9 orders of magnitude: from 2 to $2.25 \times 10^{8}$ copies ( $\mathrm{Ct}$ from 37 to 8 ). These results are similar to those reported for other viruses (Wang et al. 2006, Zhang et al. 2006), and improve those reported previously for this virus (Cutrín et al. 2009). Using this same type of standard, Pierce et al. (2013) reported an LD of 6 molecules, slightly higher than our result, and with a dynamic range 2 orders lower.

Table 7. Summary of the limit of detection (LD) of viral haemorrhagic septicaemia virus (VHSV) and dynamic range. $\mathrm{Ct}$ : threshold cycle value; Order: order of magnitude of the dynamic range

\begin{tabular}{|lcrccc|}
\hline & \multirow{2}{*}{$\begin{array}{c}\text { LD (no. of } \\
\text { copies) }\end{array}$} & \multicolumn{2}{c|}{$\begin{array}{c}\text { Dynamic range } \\
\text { Ct }\end{array}$} & Copies & \\
\hline TCID $_{50} \mathrm{ml}^{-1}$ & 1 & $14-36$ & $\sim 10^{-1}$ to $10^{6}$ & 8 \\
pDNA & $2(10 \mathrm{ag})$ & $8-37$ & 2 to $2.25 \times 10^{8}$ & 9 \\
RNAtranscript & $15(10 \mathrm{ag})$ & $11-37$ & 15 to $1.5 \times 10^{8}$ & 8 \\
Pure virus & $16(100 \mathrm{ag})$ & $13-36$ & 16 to $1.6 \times 10^{8}$ & 8 \\
Crude virus & $160(1 \mathrm{fg})$ & $14-35$ & 160 to $1.6 \times 10^{8}$ & 7 \\
\hline
\end{tabular}


The LD using an RNA transcript was raised to 15 copies, and with a dynamic range of 8 orders of magnitude: from 15 to $1.5 \times 10^{8}$ (Ct between 37 and 11). This result is similar to those reported for other viruses (Hoffmann et al. 2005, Workenhe et al. 2008), and features a much higher sensitivity than that reported by Garver et al. (2011) for the same virus (100 copies).

The use of a purified virus as the standard yielded the same LD as with a transcript (16 copies), which was expected because, to our understanding, the use of a transcript as a template is what best resembles the genomic RNA, and the purification of the virus ensures that only genomic RNA is available as a template. In terms of quantity of RNA, 100 ag is 10-fold lower than the LD observed with crude virus, and also 19-fold lower than that previously reported with a multiplex procedure (Cutrín et al. 2009).

These differences between the different standards have been widely described in the literature (Dopazo \& Bandín 2011) and represent a handicap when results must be compared between studies. Therefore, the design of the present study was extended to ensure the reliability of the standard curves with each standard and chemistry, which would allow them to be compared. For that reason, the evaluation of the sensitivity with each type of reference was carried out with 3 replicates per day and 3 repetitions: on 3 different days by 3 different people. This design not only provided reliable LDs, but also allowed us to evaluate the repeatability and reproducibility of the procedure and, hence, the reliability of the final curve obtained for each standard and chemistry. As a result, we have demonstrated high levels of repeatability and reproducibility in all the experiments, regardless of the viral strain tested, as well as a high robustness, given that no significant effect of the experience of the worker was observed. In addition, all the standard curves showed high $\mathrm{R}^{2}$ values and efficiencies within the range 90 to $110 \%$, with all strains and standards, and regardless of the type of chemistry employed. All of these results support the high efficiency and reliability of this procedure for the diagnosis of VHSV isolates from any genotype.

The advantages and disadvantages of using realtime PCR with SYBR Green or with TaqMan probes are well documented (Dopazo \& Bandín 2011). Consequently, SYBR Green RT-PCR is considered a flexible and cost-effective approach that can be directly applied without the need to design and synthesize fluorescently labeled target-specific probes (Martínez et al. 2008), and is less dependent on sequence variations. In addition, the post-amplification melting curve analysis provides highly specific detection (Kong et al. 2009), although further research is needed to ensure the specificity of the Tm. On the other hand, the advantage of using TaqMan chemistry for qRT-PCR lies in the highly improved specificity due to the use of a labelled internal probe. However, its disadvantage is the increased cost of the diagnosis with respect to the SYBR Green chemistry. Since our procedures have been demonstrated to provide standard curves statistically indistinguishable between both chemistries, the selection of either of them will only depend upon the preferences of each laboratory, ensuring the same reliability of diagnosis and quantification.

Data generated by real-time RT-PCR can be used to quantify native templates using either absolute or relative approaches. Absolute quantification requires the construction of a standard curve using relevant standards (Bustin 2000, Bustin et al. 2005, Wong \& Medrano 2005); relative quantification describes the change in expression of the target gene relative to an internal normalised reference gene, usually a housekeeping gene (Giulietti et al. 2001). However, housekeeping genes are not necessarily appropriate references for qRT-PCR data normalisation except for estimating the quality of the RNA in a sample or for detecting the presence of inhibitory factors (Sellars et al. 2007). In the present study, we decided to choose an absolute quantification approach because to our understanding, it is a better approach for estimating the real number of copies of viral RNA in a sample. Nevertheless, we did include housekeeping genes ( $\beta$ actin and $18 \mathrm{~S}$ were tested) in the initial experiments (data not shown) to ensure that RNA extraction was correct. However, they were soon removed since they did not provide any special benefits or improve the procedure and, on the contrary, they made it more complicated and expensive. The repeatability and reproducibility of all of the results support our decision. In addition, other authors have reported the use of this same approach for quantification (Purcell et al. 2006, Bain et al. 2010).

The high repeatability and reproducibility also supports the use of the final standard curves as a reference for quantification, as long as the proposed protocol is followed as indicated. Given that no significant differences between the slopes of the standard curves of quantification were observed between the different references, which means that they can be considered parallel, a unique conversion factor between each pair of standards can be used to compare results from different studies that have used different templates as a reference for quantification, 
and this will be very useful in the future, even to compare further studies with previous reports. Nevertheless, additional studies are being conducted to validate the procedures in infected fish samples.

Acknowledgements. This work was partially supported by grants EM201/2005 from the Xunta de Galicia, CSD200700002 Aquagenomics (funded by the Consolider-Ingenio 2010 program) from the Ministerio de Ciencia e Innovación, and MHE2011-00116 from the Ministerio de Educación.

\section{LITERATURE CITED}

Bain MB, Cornwell ER, Hope KM, Eckerlin GE and others (2010) Distribution of an invasive aquatic pathogen (viral hemorrhagic septicemia virus) in the Great Lakes and its relationship to shipping. PLoS ONE 5:e10156

Bustin SA (2000) Absolute quantification of mRNA using real-time reverse transcription polymerase chain reaction assays. J Mol Endocrinol 25:169-193

> Bustin SA, Benes V, Nolan T, Pfaffl MW (2005) Quantitative real-time RT-PCR - a perspective. J Mol Endocrinol 34: 597-601

> Chico V, Gomez N, Estepa A, Perez L (2006) Rapid detection and quantification of viral hemorrhagic septicemia virus in experimentally challenged rainbow trout by real-time RT-PCR. J Virol Methods 132:154-159

Cutrín JM, Olveira JG, Bandín I, Dopazo CP (2009) Validation of real time RT-PCR applied to cell culture for diagnosis of any known genotype of viral haemorrhagic septicaemia virus. J Virol Methods 162:155-162

Dopazo CP, Bandín I (2011) Techniques of diagnosis of fish and shellfish virus and viral diseases. In Nollet LML, Toldra F (eds) Safety analysis of foods of animal origin. CRC Press, Boca Raton, FL, p 531-576

> Dopazo CP, Bandín I, López-Vazquez C, Lamas J, Noya M, Barja JL (2002) Isolation of viral hemorrhagic septicemia virus from Greenland halibut Reinhardtius hippoglossoides caught at the Flemish Cap. Dis Aquat Org 50: 171-179

> Garver KA, Hawley LM, McClure CA, Schroeder T and others (2011) Development and validation of a reverse transcription quantitative PCR for universal detection of viral hemorrhagic septicemia virus. Dis Aquat Org 95: 97-112

Giulietti A, Overbergh L, Valckx D, Decallonne B, Bouillon R, Mathieu C (2001) An overview of real-time quantitative PCR: applications to quantify cytokine gene expression. Methods 25:386-401

Hoffmann B, Beer M, Schelp C, Schirrmeier H, Depner K (2005) Validation of a real-time RT-PCR assay for sensitive and specific detection of classical swine fever. J Virol Methods 130:36-44

> Hope KM, Casey RN, Groocock GH, Getchell RG, Bowser PR, Casey JW (2010) Comparison of quantitative RT-PCR with cell culture to detect viral hemorrhagic septicemia virus (VHSV) IVb infections in the Great Lakes. J Aquat Anim Health 22:50-61

> Jensen MH (1965) Research on the virus of Egtved disease. Ann NY Acad Sci 126:422-426

Jiang W, Wang P, Yu H, Zhang Y, Zhao K, Du H, Bai X (2014) Development of a SYBR Green I based one-step realtime PCR assay for the detection of Hantaan virus. J Virol
Methods 196:145-151

Jonstrup SP, Kahns S, Skall HF, Boutrup TS, Olesen NJ (2013) Development and validation of a novel Taqmanbased real-time RT-PCR assay suitable for demonstrating freedom from viral haemorrhagic septicaemia virus. J Fish Dis 36:9-23

$>$ Kong LL, Omar AR, Bejo MH, Ideris A, Tan SW (2009) Development of SYBR green I based one-step real-time RT-PCR assay for the detection and differentiation of very virulent and classical strains of infectious bursal disease virus. J Virol Methods 161:271-279

> Kurath G, Leong J (1985) Characterization of infectious hematopoietic necrosis virus mRNA species reveals a nonvirion rhabdovirus protein. J Virol 53:462-468

> Liu Z, Teng Y, Liu H, Jiang Y and others (2008) Simultaneous detection of three fish rhabdoviruses using multiplex real-time quantitative RT-PCR assay. J Virol Methods 149:103-109

> López-Vázquez C, Raynard RS, Bain N, Snow M, Bandín I, Dopazo CP (2006) Genotyping of marine viral haemorrhagic septicaemia virus isolated from the Flemish Cap by nucleotide sequence analysis and restriction fragment length polymorphism patterns. Dis Aquat Org 73:23-31

Martínez E, Riera P, Sitjà M, Fang Y, Oliveira S, Maldonado J (2008) Simultaneous detection and genotyping of porcine reproductive and respiratory syndrome virus (PRRSV) by real-time RT-PCR and amplicon melting curve analysis using SYBR Green. Res Vet Sci 85:184-193

Matejusova I, McKay P, McBeath AJA, Collet B, Snow M (2008) Development of a sensitive and controlled realtime RT-PCR assay for viral haemorrhagic septicaemia virus (VHSV) in marine salmonid aquaculture. Dis Aquat Org 80:137-144

OIE (World Organisation for Animal Health) (2012) Manual of diagnostic tests for aquatic animals, 7th edn. OIE, Paris

> Pierce LR, Willey JC, Palsule VV, Yeo J, Shepherd BS, Crawford EL, Stepien CA (2013) Accurate detection and quantification of the fish viral hemorrhagic septicemia virus (VHSv) with a two-color fluorometric real-time PCR assay. PLoS ONE 8:e71851

> Purcell MK, Hart SA, Kurath G, Winton JR (2006) Strandspecific, real-time RT-PCR assays for quantification of genomic and positive-sense RNAs of the fish rhabdovirus, infectious hematopoietic necrosis virus. J Virol Methods 132:18-24

Sambrook J, Russell DW (eds) (2001) Molecular cloning. A laboratory manual, Vol 3, 3rd edn. Cold Spring Harbor Laboratory Press, Cold Spring Harbor, NY

Schütze H, Mundt E, Mettenleiter TC (1999) Complete genomic sequence of viral hemorrhagic septicemia virus, a fish rhabdovirus. Virus Genes 19:59-65

Sellars M, Vuocolo T, Leeton L, Coman G, Degnan B, Preston N (2007) Real-time RT-PCR quantification of Kuruma shrimp transcripts: a comparison of relative and absolute quantification procedures. J Biotechnol 129:391-399

> Wang X, Ao J, Li Q, Chen X (2006) Quantitative detection of a marine fish iridovirus isolated from large yellow croaker, Pseudosciaena crocea, using a molecular beacon. J Virol Methods 133:76-81

> Wong M, Medrano J (2005) Real-time PCR for mRNA quantification. Biotechniques 39:75-85

Workenhe ST, Kibenge MJ, Iwamoto T, Kibenge FS (2008) Absolute quantification of infectious salmon anaemia virus using different real-time reverse transcription PCR chemistries. J Virol Methods 154:128-134 
Yue Z, Teng Y, Liang C, Xie X and others (2008) Development of a sensitive and quantitative assay for spring viremia of carp virus based on real-time RT-PCR. J Virol Methods 152:43-48

Editorial responsibility: Mark Crane, Geelong, Victoria, Australia
Zhang H, Wang J, Yuan J, Li L, Zhang J, Bonami JR, Shi Z (2006) Quantitative relationship of two viruses ( $M r N V$ and XSV) in white-tail disease of Macrobrachium rosenbergii. Dis Aquat Org 71:11-17

Submitted: August 7, 2014; Accepted: December 16, 2014 Proofs received from author(s): May 11, 2015 